\title{
THE ROLE OF ARTIFICIAL INTELLIGENCE TECHNIQUES IN IMPROVING THE BEHAVIOR AND PRACTICES OF FACULTY MEMBERS WHEN SWITCHING TO E- LEARNING IN LIGHT OF THE COVID-19 CRISIS
}

\author{
Shimaa Abdullah \\ Nagro
}

\author{
Department of Computer Science College of Computing and Informatics Saudi Electronic University, \\ Kingdom of Saudi Arabia. \\ Email:s.nagro@seu.edu.sa.Tel:+966541512525
}

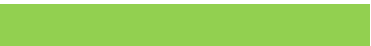

Article History

Received: 30 June 2021

Revised: 23 September 2021

Accepted: 25 October 2021

Published: 11 November 2021

\section{Keywords}

AI in education

Artificial intelligence

Conventional education

COVID-19

e-learning

Pandemic

\section{$A B S T R A C T$}

This study investigated the role of e-learning and artificial intelligence (AI) in improving the faculty members' practices when switching to online education in the wake of the COVID-19 pandemic. The researcher employed a descriptive and analytical approach. A questionnaire was used to measure the impact of AI and e-learning on four different themes related to education in Saudi Arabia. The data from 406 respondents suggested a statistically significant $(\alpha \leq 0.05)$ effect of AI on e-learning. The faculty members strongly agreed that AI and e-learning improved relevant aims of teaching and related practices during the pandemic. Moreover, the influence on practices related to teaching methods during the pandemic was also highly positive. Further, the instructors strongly acknowledged that e-learning and AI ameliorated their teaching practices in general. Finally, the study depicted that e-learning and AI assisted instructors to automate grading and evaluation, ensures the confidentiality of data, and provides easier access to information. The average of the sample responses for all four fields analyzed in the study corresponded to the degree of approval. This study has a paramount importance due to the continuity of education in the context of the COVID19 pandemic and the role of e-learning and artificial intelligence in education in general.

Contribution/Originality: This study is one of very few studies which have investigated the efficiency of applying AI techniques in e-learning during COVID-19 pandemic. It also investigated the faculty members' practices to improve teaching methods and quality during the pandemic. The findings could provide insights for universities' leaders to improve e-learning process.

\section{INTRODUCTION}

In 2020, the COVID-19 virus spread as a pandemic worldwide and led to numerous changes in the education sector, which was severely affected. To reduce the spread of the pandemic, physical distancing measures were adopted (Crawford et al., 2020). The education in schools was substituted with e-learning at home. Several online learning websites offered free access to their services as part of demand. Online classrooms have been widely in-use since mid-February, 2020. Gradually, students have evolved to accept e-learning and are seeking to adapt to new circumstances (Chick et al., 2020).

A significant proportion of teachers is eager to switch to the online mode of learning globally. Online education is, however, not a new mode of delivery for universities. Most faculty are already trained to use online learning tools as an alternative way of teaching, though the sudden transition to online education raised concerns about the faculty's ability to adapt to new technologies. Working from home could be a difficult job for teachers, and their 
perspectives could change towards teaching methods. Many universities also did not have enough infrastructure or resources to promote online teaching immediately.

The transition from face-to-face to online teaching has a significant impact on students' evaluation. Although technology has been commonly used to support teaching and learning, the assessment procedures are still underdeveloped (Timmis, Broadfoot, Sutherland, \& Oldfield, 2016). Moreover, due to the current pandemic, the students and teachers do not know what steps should be taken regarding the management of unfinished tasks, projects, and other assignments (Raaheim et al., 2019). If the exams are taken online, it is not easy to monitor the students to ensure transparency. Through online means, training, practical exams, and performance tests also cannot be conducted. Furthermore, the students who do not have readily available internet facilities face a significant disadvantage when engaging in the online assessment processes that affect their average grade point (Alruwais, Wills, \& Wald, 2018).

The advances in emerging e-learning technologies and techniques, such as artificial intelligence techniques (AI) have introduced new educational possibilities; nevertheless, it is essential to mention that education is a humancentric task and not a technological issue. Despite rapid developments in AI, it is a risky path to rely on technology. It is also essential to maintain focus on the notion that humans should identify glitches, troubleshoot problems, manage risks, and ask questions to enhance their understanding and creative thinking. The role of humans in education has also left the doors open to novelty in teaching.

Previous research has proposed that teachers can better understand online teaching through training programs (Lee, March, \& Peters, 2015). Some of the studies identified a series of motivating and discouraging factors that can influence educators' enthusiasm to teach online (Shreaves, 2019). The views of the faculty on online education must be understood in order to address their concerns adequately. The acceptance of new technologies that will eventually help in developing learning management systems at universities also requires a faculty perspective (Farhan, Razmak, Demers, \& Laflamme, 2019). In this backdrop, the current research sought to determine the reaction of faculty members in Saudi universities towards employing e-learning and taking advantage of artificial intelligence systems to improve the quality of education and raise the level of educational gains for students in light of the COVID-19 pandemic.

\section{RESEARCH QUESTIONS}

This study consisted of one central question and three sub-questions. The central question was, "what is the role of e-learning and AI techniques in improving the behavior and practices of faculty members when switching over from traditional education to e-learning in the light of the COVID-19 crisis?"

Based on the main question mentioned above, three sub-questions were explored:

1. What is the role of AI techniques in improving relevant practices during a pandemic?

2. What is the role of AI techniques in improving teaching practices during the pandemic?

3. What is the role of AI techniques in improving faculty practices in general during the pandemic?

\section{RESEARCH HYPOTHESES}

The current study consists of one primary hypothesis and three sub-hypotheses. The main hypothesis was "There is no statistically significant effect at the $\alpha \geq 0.05$ level of AI techniques on improving the behavior and practices of faculty members when switching from traditional education to e-learning in the light of COVID-19 crisis".

The following sub-hypotheses were developed from the main hypothesis:

1. There is no statistically significant effect at the $\alpha \geq 0.05$ level of AI techniques on improving relevant practices during a pandemic. 
2. There is no statistically significant effect at the $\alpha \geq 0.05$ level of AI techniques on improving teaching practices during the pandemic.

3. There is no statistically significant effect at the $\alpha \geq 0.05$ level of AI techniques on improving faculty practices in general during the pandemic.

\section{OBJECTIVES OF STUDY}

The current study consisted of a main objective and three sub-objectives. The main objective was "to identify the role of AI techniques in improving the behavior and practices of faculty members when switching from traditional education to e-learning in light of the COVID-19 crisis."

From the main objective, three sub- objectives were stated:

1. To learn about the role of $\mathrm{AI}$ in improving relevant practices during a pandemic.

2. To explore the role of AI in improving teaching practices during the pandemic.

3. To investigate the role of AI in improving faculty practices during the pandemic.

\section{LITERATURE REVIEW}

\subsection{Artificial Intelligence and Education}

Artificial intelligence in education focuses on research, development, and evaluation of teaching and learning applications. There have been several long-term goals, such as comprehension and learning of nuanced student responses, discerning when and why a student's understanding has fallen apart, providing clues to helping students understand the study materials, and eventually simulating the conduct and guidance of a human tutor in this context. The researcher envisaged personalized tutors who adapt to each student's needs or teach student groups based on gender classification, level of achievement, lesson time, etc. Artificial intelligence techniques include interpreting complex student answers, getting to know learner's performance, and understanding when/why the understanding of a student has fallen, and providing hints about the same. Approaching, learning, planning, language processing, and responding are the main objectives of artificial intelligence research (Woolf, 2015). The education sector can effectively employ AI. In this context, Xu (2019) evaluated the effect of AI on education.

Artificial intelligence research has culminated in advances and inventions in the recent past resulting in computers, software, and other devices demonstrating human-like intelligence distinguished by cognitive abilities, comprehension, adaptability, and decision-making capability. AI techniques has extensively been embraced and used in learning, particularly by teaching institutions, in various forms. Initially, AI took the shape of computer technology and then transitioned to internet advertisement platforms, advanced education systems, and finally embedded computer systems. Among other advancements, AI allowed humanoid robots and web-based robots to execute the roles and duties of teachers individually or with instructors. These tools have helped educators conduct various administrative tasks, such as efficiently reviewing and marking assignments and ensuring greater teaching material quality. Therefore, courses have been tailored to students' new needs to improve their learning experience.

Contact North Contact Nord—a distance education and training network-addressed some features, facts, and challenges regarding artificial intelligence techniques in teaching and learning (Contact North Contact Nord, 2018) as follows:

- $\mathrm{AI}$ is challenging to implement at the institutions that attempt to initiate and expand AI systems. Such defies include: who will manage and defend an AI initiative.

- Artificial intelligence refers to computer systems that mimic human actions. Hence, as a whole, AI denotes the computer systems that carry out tasks that typically require human expertise.

- The long-lasting goal of developing learning programs in response to students' unique skills, needs, and previous experience is now feasible through AI. 
- $\quad$ AI paves the path for customized and adaptive learning. Such adaptive learning systems draw on previous student experience and offer guidance in future learning directions.

- AI allows schools to provide students with $24 / 7$ customized support for managing the challenges of campus life and optimizing their campus experience.

- AI can also be used for students' evaluation. Although machines cannot comprehend the complexities of text or expression, AI is increasingly and effectively being used in evaluating learners' work.

- The experience of disabled students can be improved by AI, which is very promising in enriching the learning environment for such students.

- AI improves learning and analytical capabilities and includes measuring, gathering, evaluating, and recording data, which can assist in bettering teaching and studying.

Nguyen et al. (2020) claimed that AI technology has made great strides in our everyday lives and helped people fight against COVID-19. While numerous studies have been published on COVID-19, the researches on AI applications and contributions in this war in the context of education are limited. This is partly because of the restricted availability of COVID-19 data in this specific background. The computational models usually need a lot of data for learning and analysis. Nonetheless, it is anticipated that the focus on AI studies related to COVID-19 will augment substantially in the coming years when more data would become available. For this purpose, repositories should be developed and made available to researchers worldwide to use the available data in their research.

\subsection{Online Learning or E-Learning}

Technology has been playing a prominent role during the present crisis. E-learning techniques have been helping the learners to study at home. Educators' roles in the education changes, especially when they switch from conventional classroom to virtual teaching. Improvements to such transition are continually being made by validating new teaching and learning ideas and offering encouragement to learning emerging technologies. Distance education is often commonly referred to as online education since the students are physically far away from their place of education. With the implementation of technology in higher education, the primary responsibilities of people interested in distance and online education have changed. Educational theorists have examined how and where education theories, including social constructivism, communication, and learning and practice groups, can be used in the online world to accelerate learning. Frameworks and models have also emerged to teach and design the educational materials, as suggested by Nagro and Campion (2017). These include the technological, teaching, knowledge information, and research community models. Such frameworks help in recognizing new or updated educators' roles, abilities, and skills. Traditionally, remote education providers used to hire part-time educators to undertake the needs of distance learners. Indeed, the instructors need new skills and knowledge as they are heading into the online world. It is anticipated that the universities, jointly with online educational services providers, will analyze and support the evolving roles and skills through trainings (Ní Shé et al., 2019).

Amid the deadly pandemic of COVID-19, online platforms are crucial for learning. Additionally, the wide availability of information technologies offers opportunities for exploiting these resources to continue education. In the current era, internet access is satisfactory, and through readily available tools, video conferencing with 40 to 50 students is comfortably possible. Moreover, discussions may take place with the students to keep the classes interactive, while lectures are also available on mobile phones and laptops (Basilaia, Dgebuadze, Kantaria, \& Chokhonelidze, 2020).

He (2020) proposed to continue the college teaching of English throughout the COVID-19 virus shut down period via online learning where both teachers and learners can build an interactive learning environment. In Saudi Arabia, because students' expectations were in favor of e-learning for English as a Foreign Language (ESL) and English as a Second Language (EFL) classes, the researchers called for its adoption as a viable means of learning 
during the pandemic owing to its significant benefits and marginal drawbacks (Ahmad, 2020). The benefits of elearning and its potential in education is also evident from the reports which have mentioned improved writing quality by using cloud-based collaboration through Google Docs (Ahmad, 2020); Telegram preferred EFL vocabulary learning (Abu-Ayfah, 2020); the use of mobile technology for improving student-teacher connectivity (Alshehri, Rutter, \& Smith, 2019) and Nearpod platform for enhancing collaboration among students (Hakami, 2020). Other researchers also investigated and illustrated the paramount role of e-learning in the COVID-19 crisis (Kaur, Sahdev, Chaturvedi, \& Rajawat, 2020).

\subsection{The Transition of Teaching Quality from Traditional Education to E-learning}

In comparison with the evaluation of the quality of science comprehended by quantitative methods, the quality of education remained a contentious field for years. Nevertheless, approaches such as class observations, analysis of student statistics, peer reviews, and teacher interviews have made significant efforts to assess teaching efficiency objectively. The students' assessment has also become a priority method because, as many sources have pointed out, the teaching performance can be measured at the student level as the direct recipient of teaching (Steinberg \& Garrett, 2016). Ustünlüoğlu (2016) suggested that a measure of the academic success or degree expectancy of a university should be taken into account in order to provide an in-depth analysis of the findings in other variables, including ethnicity, gender, and average grade point. The quality of the education would improve through an emphasis on the student needs and desires, a comparison of the teaching staff's performance and competencies, and the development of good higher education assessment systems.

The quality of teaching can be evaluated by the traces of educational activities that are increasingly created, processed, analyzed, and organized in a way that not only assesses but also educates people in the first place. However, the readers should carefully consider the following points to understand the aspects of quality of education:

- Not only what is learned, but how it is learned is to be understood.

- The student evaluations and surveys of customer satisfaction help proponents improve the standard of education because 'clients have power over their preferences and evaluation programs by fulfilling their demands' (Bunce, Baird, \& Jones, 2017).

- The focus on student experience, evaluation, and optimization can be seen as a method of control by systematically calculating, controlling, and schematizing each feature and process to ensure the quality of the educational product and increase the education system's efficiency through a homogenized learning experience (Hayes, 2017).

- The performance of an instructor depends on how he fits into the educational setting and how he shapes the same.

\subsection{Teachers' Perception toward the E-Learning Classes}

Perception is a thought about something, which can be expressed through attitude. The experiences of teachers form an essential part of the learning process. Therefore, the interpretation of the teacher about e-learning would affect the actions of the students. One major reason for studying teachers' perceptions is that their beliefs also impact the students' behaviors. Hence, the evaluation of teachers should be part of an appraisal for effective learning. Researchers observed that, since the 1980s, teachers' assumptions became increasingly recognized as a technique for estimating the quality of the learning process (Azjen \& Fishbein, 1980; Windiarti, Fadilah, Dhermawati, \& Pratolo, 2019).

The attitudes of the educators concerning technology affect their ability to use and incorporate it into the curriculum and teaching. That is why the tech teachers, having programming knowledge, depict a constructive approach to technology adoption. Hence, computer knowledge has a direct connection to teaching behavior. The 
more informed the teachers about technology are, the more likely they are to demonstrate positive attitudes towards using it in education (Yanti \& Setiawan, 2018). Afzal, Safdar, and Ambreen (2015) explored the teachers' perceptions of employing information and communication technology (ICT) in physics to develop a systematic theoretical base and apply the developed framework for e-learning environments, demonstrating that teachers had a positive attitude towards technology. The students also considered technological ways of teaching to be superior to the conventional ones, and they were more welcoming to online learning material.

Severe Acute Respiratory Syndrome 2 (SARS-CoV-2) emerged at the end of 2019 and spread globally. In March 2020, the World Health Organization declared SARS-Cov-2 a global pandemic (Di Gennaro et al., 2020). In order to avoid any probable potential health care crises, the educational campuses were closed. In this scenario, a big challenge to the education sector was how institutions could continue to provide schooling if they decide to cancel the in-person classes? Since the pandemic, an increasing number of students are taking classes online as a short-term solution. Of course, switching to online learning is not an ideal solution: not many professors have taught online before, and technical support is often lacking; however, many institutions are looking to online learning as a way to save student education in the wake of the current situation. It can be anticipated that this group of learners and teachers will provide insights into the use of technology for educational purposes in uncertain times (Dill, Fischer, McMurtrie, \& Supiano, 2020).

This study investigated the concept and various aspects of e-learning and its role in online-teaching when switching from traditional learning, keeping in view the current pandemic. The main objective was to investigate the role of AI techniques to facilitate this sudden transformation to faculty members, It also investigate the faculty members' perspectives regarding AI techniques and e-learning in education amid the COVID-19 crisis. The sampling population belonged to Saudi Arabian institutions. A descriptive-analytical approach was undertaken to analyze data.

\section{METHODOLOGY}

\subsection{Study Design}

A descriptive analytical approach was used to illustrate the faculty members' perspectives in Saudi Arabian universities regarding practices related to teaching methods, faculty members' practices generally, and the role of applying artificial intelligence techniques in e-learning management systems in the wake of COVID-19virus pandemic. The researcher conducted the study by identifying the problem, developing the questionnaire, selecting appropriate samples, collecting data, classifying and coding the data, and then describing, analyzing, and interpreting results.

\subsection{Sample Size and Type}

The study population consisted of teaching staff members in Saudi Arabia's public sector universities. The data were collected using survey monkey by distributing the survey to all faculty members through emails. The samples were picked randomly from the universities, along with demographic variables and educational qualification data. It was ensured that the participants understood AI techniques and its implementation by providing concise definitions of the terms in the survey. The faculty members' responses were collected on a five-point Likert scale ranging from strongly disagrees to strongly agree. Four themes of e-learning and the role of artificial intelligence were covered, including 1) The lecture aims related practices during the pandemic, 2) Practices related to teaching methods during the pandemic, 3) The faculty members' practices in general during the pandemic, and 4) The use of artificial intelligence techniques in e-learning management systems used by the college during the pandemic. A total of 406 samples were recorded from various institutions of the country. 


\subsection{Statistical Analysis of the Data}

Pearson's correlation analysis was done to assess construct validity. For reliability testing, Cronbach's alpha coefficient was determined for the four dimensions of the study. Moreover, the normal distribution of the samples was confirmed using the Kolmogorov-Smirnov test.

Table-1. Demographic data of the sampling population.

\begin{tabular}{|c|c|c|c|}
\hline Variables & Categories & Frequency & Percent \\
\hline \multirow{2}{*}{ Sex } & male & 146 & $36 \%$ \\
\hline & female & 260 & $64 \%$ \\
\hline \multirow{2}{*}{ Nationality } & Saudi & 271 & $66.7 \%$ \\
\hline & Non-Saudi & 135 & $33.3 \%$ \\
\hline \multirow{4}{*}{ Age } & $20-30$ & 24 & $5.9 \%$ \\
\hline & $31-40$ & 194 & $47.8 \%$ \\
\hline & $41-50$ & 132 & $32.5 \%$ \\
\hline & $51+$ & 56 & $13.8 \%$ \\
\hline \multirow{5}{*}{ Level of education } & Bachelor's degree & 21 & $5.2 \%$ \\
\hline & Master's degree & 89 & $21.9 \%$ \\
\hline & Ph.D. degree (Assistant professor) & 203 & $50 \%$ \\
\hline & Associate professor & 77 & $19 \%$ \\
\hline & Professor & 16 & $3.9 \%$ \\
\hline \multirow{15}{*}{ Major } & Business administration and accounting & 28 & $6.9 \%$ \\
\hline & E-commerce & 13 & $3.2 \%$ \\
\hline & Medicine and health sciences & 47 & $11.6 \%$ \\
\hline & Computer science and information technology & 97 & $23.9 \%$ \\
\hline & Law & 23 & $5.7 \%$ \\
\hline & Digital media & 3 & $0.7 \%$ \\
\hline & English language and translation & 20 & $4.9 \%$ \\
\hline & Arabic studies & 12 & $3 \%$ \\
\hline & $\begin{array}{l}\text { Natural Science (Biology, Chemistry, Mathematics, } \\
\text { Physics, and Earth \& ocean sciences) }\end{array}$ & 65 & $16 \%$ \\
\hline & Engineering & 8 & $2 \%$ \\
\hline & $\begin{array}{l}\text { Social sciences including History, Linguistics, } \\
\text { Psychology, and Women's studies }\end{array}$ & 13 & $3.2 \%$ \\
\hline & Economics & 7 & $1.7 \%$ \\
\hline & Art & 3 & $0.7 \%$ \\
\hline & Islamic studies & 28 & $6.9 \%$ \\
\hline & others & 39 & $9.6 \%$ \\
\hline \multirow{3}{*}{ Experience at traditional teaching } & Less than one year & 38 & $9.4 \%$ \\
\hline & From 1 to 3 years & 81 & $20 \%$ \\
\hline & More than 3 years & 287 & $70.7 \%$ \\
\hline \multirow{3}{*}{ Experience at e- learning } & Less than one year & 164 & $40.4 \%$ \\
\hline & From 1 to 3 years & 111 & $27.3 \%$ \\
\hline & More than 3 years & 131 & $32.3 \%$ \\
\hline \multirow{3}{*}{$\begin{array}{l}\text { Experience at using artificial } \\
\text { intelligence technique }\end{array}$} & Less than one year & 233 & $57.4 \%$ \\
\hline & From 1 to 3 years & 103 & $25.4 \%$ \\
\hline & More than 3 years & 70 & $17.2 \%$ \\
\hline \multirow{5}{*}{$\begin{array}{l}\text { In the early days of the pandemic, my } \\
\text { institution trained the faculty members } \\
\text { in the learning management system } \\
\text { that we are going to use }\end{array}$} & Strongly disagree & 4 & $1 \%$ \\
\hline & Disagree & 15 & $3.7 \%$ \\
\hline & Neither agree nor disagree & 59 & $14.5 \%$ \\
\hline & Agree & 147 & $36.2 \%$ \\
\hline & Strongly Agree & 181 & $44.6 \%$ \\
\hline \multirow{3}{*}{$\begin{array}{l}\text { During the pandemic, what type of } \\
\text { learning management system does } \\
\text { your institution provide }\end{array}$} & Blackboard & 385 & $94.9 \%$ \\
\hline & Non & 5 & $1.2 \%$ \\
\hline & $\begin{array}{l}\text { Others (Canvas, Google classroom, Webex, Zoom, } \\
\text { M team) }\end{array}$ & 16 & $3.9 \%$ \\
\hline \multirow{3}{*}{$\begin{array}{l}\text { Have you ever used E-learning and } \\
\text { artificial intelligence techniques in } \\
\text { teaching before the COVID-19 } \\
\text { pandemic? }\end{array}$} & Never & 131 & $32.3 \%$ \\
\hline & Sometimes & 146 & $36 \%$ \\
\hline & Always & 129 & $31.7 \%$ \\
\hline
\end{tabular}

For four themes of influence of e-learning and AI techniques in the current scenario of the pandemic, the percentages of different responses to the questionnaire were calculated. Further, means were determined, ranks 
were established, and classification of the responses was done. Ultimately, dimensions means were calculated. The impact of demographic factors (age, nationality, level of education, and type of institution) was analyzed using statistical tests such as ANOVA, LSD test, t-test, as appropriate. Moreover, the impact of experience in traditional learning, e-learning, using artificial intelligence, and using e-learning and artificial intelligence techniques before the COVID-19 pandemic was also determined. Finally, hypothesis testing was done through the one-sample t-test.

\section{RESULTS}

\subsection{Collected Data}

It was noticed that the use of Blackboard as a learning management system represented the highest percentage among the faculty members. The sampling population comprised a higher number of female participants than the males. Moreover, the percentage of the native respondents was greater than the non-Saudi faculty members. Regarding the participants' ages, the largest percentage was constituted by the faculty members ranging in age from 30 to 40 years.

\subsection{Demographic Variables}

The sampling population was constituted of 406 university faculty members. The figures about the demographic variables of the samples are presented in Table 1.

\subsection{Construct Validity}

The construct validity is one of the measures that depicts the validity of the approaches employed in research. It determines the extent to which the objective, the tool is intended to accomplish, is achieved. Further, it shows the level of association between each field of study and the overall degree of the questionnaire paragraphs.

In this study, the highest correlation coefficient (.121) was observed for the field "Practices related to teaching methods during the pandemic." The positive correlation was weak but statistically significant. The correlation coefficient for the field practices during the pandemic was equal to .047. It was also a weak, direct, and statistically significant correlation. The other two fields analyzed in this study depicted inverse correlation. The correlation coefficient value for the domain, the faculty members' practices in general during the pandemic, was -.097; while the field "Application of artificial intelligence techniques" demonstrated the maximum and highly significant negative correlation coefficient of -0.215 Table 2 .

Table-2. Results of the construct validity.

\begin{tabular}{l|c|c}
\hline Field & Pearson's Correlation Coefficient & Sig. \\
\hline Practices during the pandemic & $0.047^{*}$ & 0.002 \\
\hline Practices related to teaching methods during the pandemic & $0.121^{*}$ & 0.017 \\
\hline The faculty members practices in general during the pandemic & $-0.097-^{*}$ & 0.019 \\
\hline Application of artificial intelligence techniques & $-0.215-^{* *}$ & 0.000 \\
\hline
\end{tabular}

Table-3. Cronbach's alpha coefficient of reliability.

\begin{tabular}{|c|c|c|}
\hline Field & $\begin{array}{l}\text { Number of } \\
\text { paragraphs }\end{array}$ & $\begin{array}{c}\text { Cronbach Alpha } \\
\text { Laboratories }\end{array}$ \\
\hline The lecture aims related practices during the pandemic & 8 & 0.348 \\
\hline Practices related to teaching methods during the pandemic & 8 & 0.741 \\
\hline The faculty members practices in general during the pandemic & 11 & 0.878 \\
\hline Applying artificial intelligence techniques & 17 & 0.640 \\
\hline All fields & 44 & 0.871 \\
\hline
\end{tabular}




\subsection{Reliability}

The reliability testing was done through the Cronbach's alpha coefficient. The results evinced a total (for all fields of the questionnaire) Cronbach's alpha coefficient value of 0.871 Table 3 . Hence, the validity and reliability of the study questionnaire for testing hypotheses was verified.

\subsection{Normal Distribution Test}

The normal distribution test is an important pre-parameter test. Table 4 shows the normal distribution of the data was corroborated using the Kolmogorov-Smirnov test. All the four fields (denoting the themes of e-learning analyzed in the study) illustrated the values of $\operatorname{sig}>.05$. The results of the test showed that the data followed a normal distribution.

Table-4. Results of Kolmogorov-Smirnov test for normal distribution of data.

\begin{tabular}{c|c|c|c}
\hline & \multicolumn{3}{|c}{ Kolmogorov-Smirnov } \\
\cline { 2 - 4 } & $\mathbf{Z}$ & Degrees of freedom & Sig. \\
\hline The field1 & 0.831 & 406 & 0.120 \\
\hline The field2 & 0.771 & 406 & 0.320 \\
\hline The field3 & 0.812 & 406 & 0.251 \\
\hline The field4 & 0.481 & 406 & 0.321 \\
\hline Total marks & 0.771 & 406 & 0.072 \\
\hline
\end{tabular}

\subsection{The Lecture Aims Related Practices during the Pandemic}

Our results indicated that faculty members strongly agreed about the influence of AI techniques and e-learning on the lecture aims related practices during the pandemic. Overall, a mean value of 4.22 was recorded for this field Table 5. The teachers strongly consented that e-learning and AI techniques improved their lecture aims related practices during the pandemic, such as live interaction with the students. Moreover, the educators strongly approved that e-learning and AI techniques facilitated in formulating educational goals, setting lectures' aims logically, taking into account the setting of goals according to the needs and inclinations of students, providing the ability to implement lesson objectives on time, and focusing on the goals that address student's difficulties. Further, the participants agreed that the technologies mentioned above helped them focus on the students' role in decisionmaking and participate with their students in formulating the goals of the course whenever possible.

\subsection{Practices Related to Teaching Methods during the Pandemic}

The faculty members strongly agreed $(m=4.12)$ on the role of AI techniques and e-learning in ameliorating their teaching methods during the pandemic Table 6.

They strongly approved that e-learning and AI techniques facilitated in preparing lectures from multiple sources, using open discussions, exploiting interesting teaching methods to excite students' motivation, employing a variety of teaching methods that contribute to the understanding of the scientific subject, and looking for new teaching methods that suit virtual classes.

Moreover, the sampling population also agreed that AI techniques and e-learning helped to use teaching methods that take into account individual differences among students. These technologies also provided the option to stop giving the lecture whenever teachers or the students felt uncomfortable. Furthermore, these techniques made it possible to employ e-lab software for teaching purposes.

\subsection{The Faculty Members Practices in General during the Pandemic}

The faculty members strongly agreed that AI techniques and e-learning bettered their teaching practices in general during the pandemic $(\mathrm{m}=4.49)$. Various aspects of coaching were evaluated in this context Table 7 . The 
teachers strongly agreed that the said technologies helped them enhance their availability to answer students' queries. The data also depicted that the faculty members enjoyed the subject they taught through virtual classes. Moreover, the educators strongly approved that these techniques helped them direct students to benefit from internet services, treat their students with appreciation and respect, deal with them fairly, cultivate confidence in them, and encourage them to extract results and ideas through discussion and questioning. Furthermore, the instructors strongly believed that these techniques did not spoil the delivery of lectures, and they could speak clearly during the virtual classes.

Also, e-learning assisted teachers in presenting study plan for the course at the beginning of the semester and recording students' absences.

\subsection{University Enables You to Apply Artificial Intelligence Techniques}

Overall, the faculty members agreed that their university enabled them to apply artificial intelligence techniques $(\mathrm{m}=3.74)$ in teaching Table 8 . They acceded that AI techniques helped them automate grades and evaluation within the educational management system, increase the confidentiality of information, and communicate efficiently with the students.

Moreover, the faculty members strongly suggested that e-learning and AI techniques benefit students in accessing information quickly. Further, the instructors agreed that AI techniques helps students solve their academic problems, guides them where they need improvement in coursework, and evaluates their knowledge to provide feedback depending on their grades. Additionally, they consented that AI techniques supports self-learning by providing students with applications and artificial intelligence-based educational programs and aids adaptive learning by developing a detailed report about the subjects that students find difficult to understand.

The data of this study evinced that teachers in Saudi Arabia had adopted online education to some extent, and they were making effective use of e-learning and AI techniques.

The academics agreed that they use virtual mentoring to track learners' progress, employ rubrics scoring tools to evaluate graded work, determine their students' knowledge using electronic exams, use smart content (digitized textbooks), and tailor educational programs to the needs of students through AI techniques. Nevertheless, the educators did not agree nor disagree regarding the advantages of using virtual facilitators or ChatBots to help students get answers to their queries. They also neither agreed nor disagreed that e-learning and IA techniques improved their teaching experience by sending a notification when they would speak too fast or too slow. 
Table-5. Influence of AI and e-learning on the first dimension: The lecture aims related practices during the pandemic.

\begin{tabular}{|c|c|c|c|c|c|c|c|c|c|c|c|c|c|}
\hline \multirow{3}{*}{ Items } & \multicolumn{10}{|c|}{ Degree of agreement } & \multirow{3}{*}{ Mean } & \multirow{3}{*}{ Rank } & \multirow{3}{*}{ Classification } \\
\hline & \multicolumn{2}{|c|}{ Strongly agree } & \multicolumn{2}{|c|}{ Agree } & \multicolumn{2}{|c|}{$\begin{array}{l}\text { Neither agree } \\
\text { nor disagree }\end{array}$} & \multicolumn{2}{|c|}{ Disagree } & \multicolumn{2}{|c|}{$\begin{array}{l}\text { Strongly } \\
\text { disagree }\end{array}$} & & & \\
\hline & $\%$ & $\mathrm{f}$ & $\%$ & $\mathrm{f}$ & $\%$ & $\mathrm{f}$ & $\%$ & $\mathrm{f}$ & $\%$ & $\mathrm{f}$ & & & \\
\hline Emphasize the live interaction between students & $47.54 \%$ & 193 & $44.83 \%$ & 182 & $5.17 \%$ & 21 & $1.48 \%$ & 6 & $0.99 \%$ & 4 & 4.36 & 1 & $\mathrm{SA}$ \\
\hline Focus on the student's role in decision-making & $29.56 \%$ & 120 & $57.64 \%$ & 234 & $10.84 \%$ & 44 & $1.23 \%$ & 5 & $0.74 \%$ & 3 & 4.14 & 7 & $\mathrm{~A}$ \\
\hline Formulate educational goals well & $40.89 \%$ & 166 & $52.71 \%$ & 214 & $5.67 \%$ & 23 & $0.49 \%$ & 2 & $0.25 \%$ & 1 & 4.33 & 3 & SA \\
\hline $\begin{array}{l}\text { Take into account the setting of goals according to the } \\
\text { needs and inclinations of students }\end{array}$ & $35.47 \%$ & 144 & $52.71 \%$ & 214 & $10.59 \%$ & 43 & $0.99 \%$ & 4 & $0.25 \%$ & 1 & 4.22 & 6 & SA \\
\hline $\begin{array}{l}\text { Arrange lectures' goals logically from easy to difficult, } \\
\text { from simple to complex }\end{array}$ & $45.81 \%$ & 186 & $45.81 \%$ & 186 & $6.90 \%$ & 28 & $0.99 \%$ & 4 & $0.49 \%$ & 2 & 4.35 & 2 & $\mathrm{SA}$ \\
\hline Have the ability to implement lesson objectives on time & $39.90 \%$ & 162 & $52.46 \%$ & 213 & $5.17 \%$ & 21 & $1.97 \%$ & 8 & $0.49 \%$ & 2 & 4.29 & 4 & SA \\
\hline Focus on the goals that address student's difficulties & $39.16 \%$ & 159 & $51.23 \%$ & 208 & $8.13 \%$ & 33 & $1.23 \%$ & 5 & $0.25 \%$ & 1 & 4.27 & 5 & SA \\
\hline $\begin{array}{l}\text { Participate with your students in formulating the goals } \\
\text { of the course whenever possible }\end{array}$ & $22.66 \%$ & 92 & $45.57 \%$ & 185 & $24.88 \%$ & 101 & $5.17 \%$ & 21 & $1.72 \%$ & 7 & 3.82 & 8 & A \\
\hline \multicolumn{11}{|l|}{ Dimension mean } & 4.22 & & SA \\
\hline
\end{tabular}

Table-6. Influence of AI and e-learning on the second dimension: Practices related to teaching methods during the pandemic.

\begin{tabular}{|c|c|c|c|c|c|c|c|c|c|c|c|c|c|}
\hline \multirow{3}{*}{ Items } & \multicolumn{10}{|c|}{ Degree of agreement } & \multirow{3}{*}{ Mean } & \multirow{3}{*}{ Rank } & \multirow{3}{*}{ Classification } \\
\hline & \multicolumn{2}{|c|}{ Strongly agree } & \multicolumn{2}{|c|}{ Agree } & \multicolumn{2}{|c|}{$\begin{array}{c}\text { Neither agree } \\
\text { nor disagree }\end{array}$} & \multicolumn{2}{|c|}{ Disagree } & \multicolumn{2}{|c|}{$\begin{array}{l}\text { Strongly } \\
\text { disagree }\end{array}$} & & & \\
\hline & $\%$ & $\mathrm{f}$ & $\%$ & $f$ & $\%$ & f & $\%$ & f & $\%$ & $f$ & & & \\
\hline $\begin{array}{l}\text { Use teaching methods that take into account } \\
\text { individual differences between students }\end{array}$ & $32.02 \%$ & 130 & $51.23 \%$ & 208 & $13.79 \%$ & 56 & $2.96 \%$ & 12 & $0.00 \%$ & $\mathrm{O}$ & 4.12 & 5 & A \\
\hline $\begin{array}{l}\text { Use a variety of teaching methods that contribute } \\
\text { to the understanding of the scientific subject } \\
\text { and suit its nature }\end{array}$ & $34.24 \%$ & 139 & $56.40 \%$ & 229 & $7.88 \%$ & 32 & $1.23 \%$ & 5 & $0.25 \%$ & 1 & 4.23 & 4 & SA \\
\hline $\begin{array}{l}\text { Look for new teaching methods that suit virtual } \\
\text { classes }\end{array}$ & $35.71 \%$ & 145 & $53.94 \%$ & 219 & $8.62 \%$ & 35 & $1.48 \%$ & 6 & $0.25 \%$ & 1 & 4.23 & 4 & SA \\
\hline $\begin{array}{l}\text { Use interesting teaching methods to excite } \\
\text { students' motivation to learn }\end{array}$ & $36.79 \%$ & 149 & $54.57 \%$ & 221 & $7.90 \%$ & 32 & $0.74 \%$ & 3 & $0.00 \%$ & $\mathrm{O}$ & 4.27 & 3 & SA \\
\hline $\begin{array}{l}\text { Use open discussion that provides an opportunity } \\
\text { to participate in the scientific subject }\end{array}$ & $40.15 \%$ & 163 & $50.99 \%$ & 207 & $7.64 \%$ & 31 & $0.99 \%$ & 4 & $0.25 \%$ & 1 & 4.29 & 2 & SA \\
\hline Prepare your lectures from multiple sources & $42.36 \%$ & 172 & $47.29 \%$ & 192 & $8.37 \%$ & 34 & $1.97 \%$ & 8 & $0.00 \%$ & 0 & 4.30 & 1 & SA \\
\hline
\end{tabular}


International Journal of Education and Practice, 2021, 9(4): 687-714

\begin{tabular}{|c|c|c|c|c|c|c|c|c|c|c|c|c|c|}
\hline $\begin{array}{l}\text { Stop giving the lecture whenever you feel the } \\
\text { students are uncomfortable }\end{array}$ & $23.15 \%$ & 94 & $45.07 \%$ & 183 & $19.70 \%$ & 80 & $11.08 \%$ & 45 & $0.99 \%$ & 4 & 3.78 & 6 & A \\
\hline $\begin{array}{l}\text { Employ teaching methods in its practical aspects } \\
\text { using E-lab software }\end{array}$ & $20.44 \%$ & 83 & $45.32 \%$ & 184 & $24.88 \%$ & 101 & $7.14 \%$ & 29 & $2.22 \%$ & 9 & 3.74 & 7 & A \\
\hline Dimension mean & & & & & & & & & & & \multicolumn{2}{|c|}{4.12} & A \\
\hline
\end{tabular}

Note: SA: strongly agree; A: agree

Table-7. Influence of AI and e-learning on the third dimension: The faculty members practices in general during the pandemic.

\begin{tabular}{|c|c|c|c|c|c|c|c|c|c|c|c|c|c|}
\hline \multirow{3}{*}{ Items } & \multicolumn{10}{|c|}{ Degree of agreement } & \multirow{3}{*}{ Mean } & \multirow{3}{*}{ Rank } & \multirow{3}{*}{ Classification } \\
\hline & \multicolumn{2}{|c|}{$\begin{array}{c}\text { Strongly } \\
\text { agree }\end{array}$} & \multicolumn{2}{|c|}{ Agree } & \multicolumn{2}{|c|}{$\begin{array}{c}\text { Neither agree } \\
\text { nor disagree }\end{array}$} & \multicolumn{2}{|c|}{ Disagree } & \multicolumn{2}{|c|}{$\begin{array}{l}\text { Strongly } \\
\text { disagree }\end{array}$} & & & \\
\hline & $\%$ & f & $\%$ & f & $\%$ & f & $\%$ & f & $\%$ & f & & & \\
\hline Enjoy the subject you offer during virtual classes & $38.42 \%$ & 156 & $50.00 \%$ & 203 & $8.13 \%$ & 33 & $2.71 \%$ & 11 & $0.74 \%$ & 3 & 4.22 & 10 & $\mathrm{SA}$ \\
\hline $\begin{array}{l}\begin{array}{l}\text { Encourage your students to ask and discuss } \\
\text { questions }\end{array} \\
\end{array}$ & $57.88 \%$ & 235 & $38.92 \%$ & 158 & $2.71 \%$ & 11 & $0.25 \%$ & 1 & $0.25 \%$ & 1 & 4.53 & 5 & SA \\
\hline $\begin{array}{l}\text { Available to answer students' inquiries by } \\
\text { conducting extra virtual office hours }\end{array}$ & $49.01 \%$ & 199 & $41.13 \%$ & 167 & $6.16 \%$ & 25 & $3.45 \%$ & 14 & $0.25 \%$ & 1 & 4.35 & 9 & SA \\
\hline $\begin{array}{l}\text { Present the study plan for the course at the } \\
\text { beginning of the semester }\end{array}$ & $59.11 \%$ & 240 & $36.70 \%$ & 149 & $3.45 \%$ & 14 & $0.74 \%$ & 3 & $0.00 \%$ & $\mathrm{O}$ & 4.54 & 4 & SA \\
\hline Speak clearly during the virtual class & $65.76 \%$ & 267 & $31.77 \%$ & 129 & $1.72 \%$ & 7 & $0.74 \%$ & 3 & $0.00 \%$ & 0 & 4.62 & 3 & $\mathrm{SA}$ \\
\hline Treat your students with appreciation and respect & $69.21 \%$ & 281 & $29.31 \%$ & 119 & $1.23 \%$ & 5 & $0.00 \%$ & $\mathrm{O}$ & $0.25 \%$ & 1 & 4.67 & 1 & SA \\
\hline Record the absences of your students continuously & $53.20 \%$ & 216 & $38.18 \%$ & 155 & $6.16 \%$ & 25 & $1.72 \%$ & 7 & $0.74 \%$ & 3 & 4.41 & 8 & SA \\
\hline $\begin{array}{l}\text { Direct your students to benefit from internet } \\
\text { services and encourage them to do so }\end{array}$ & $56.40 \%$ & 229 & $39.41 \%$ & 160 & $3.45 \%$ & 14 & $0.49 \%$ & 2 & $0.25 \%$ & 1 & 4.51 & 6 & SA \\
\hline $\begin{array}{l}\text { Provide an opportunity for your students to extract } \\
\text { results and ideas through your discussion with them }\end{array}$ & $50.99 \%$ & 207 & $44.33 \%$ & 180 & $3.69 \%$ & 15 & $0.74 \%$ & 3 & $0.25 \%$ & 1 & 4.45 & 7 & SA \\
\hline Cultivate confidence in your students & $58.13 \%$ & 236 & $38.42 \%$ & 156 & $3.20 \%$ & 13 & $0.25 \%$ & 1 & $0.00 \%$ & $\mathrm{O}$ & 4.54 & 4 & SA \\
\hline Deal with your students fairly and equitably & $66.50 \%$ & 270 & $31.77 \%$ & 129 & $1.48 \%$ & 6 & $0.25 \%$ & 1 & $0.00 \%$ & $\mathrm{O}$ & 4.64 & 2 & SA \\
\hline \multicolumn{11}{|l|}{ Dimension mean } & 4.49 & & SA \\
\hline
\end{tabular}


Table-8. Influence of AI and e-learning on the fourth dimension: University enables the teachers to apply artificial intelligence techniques

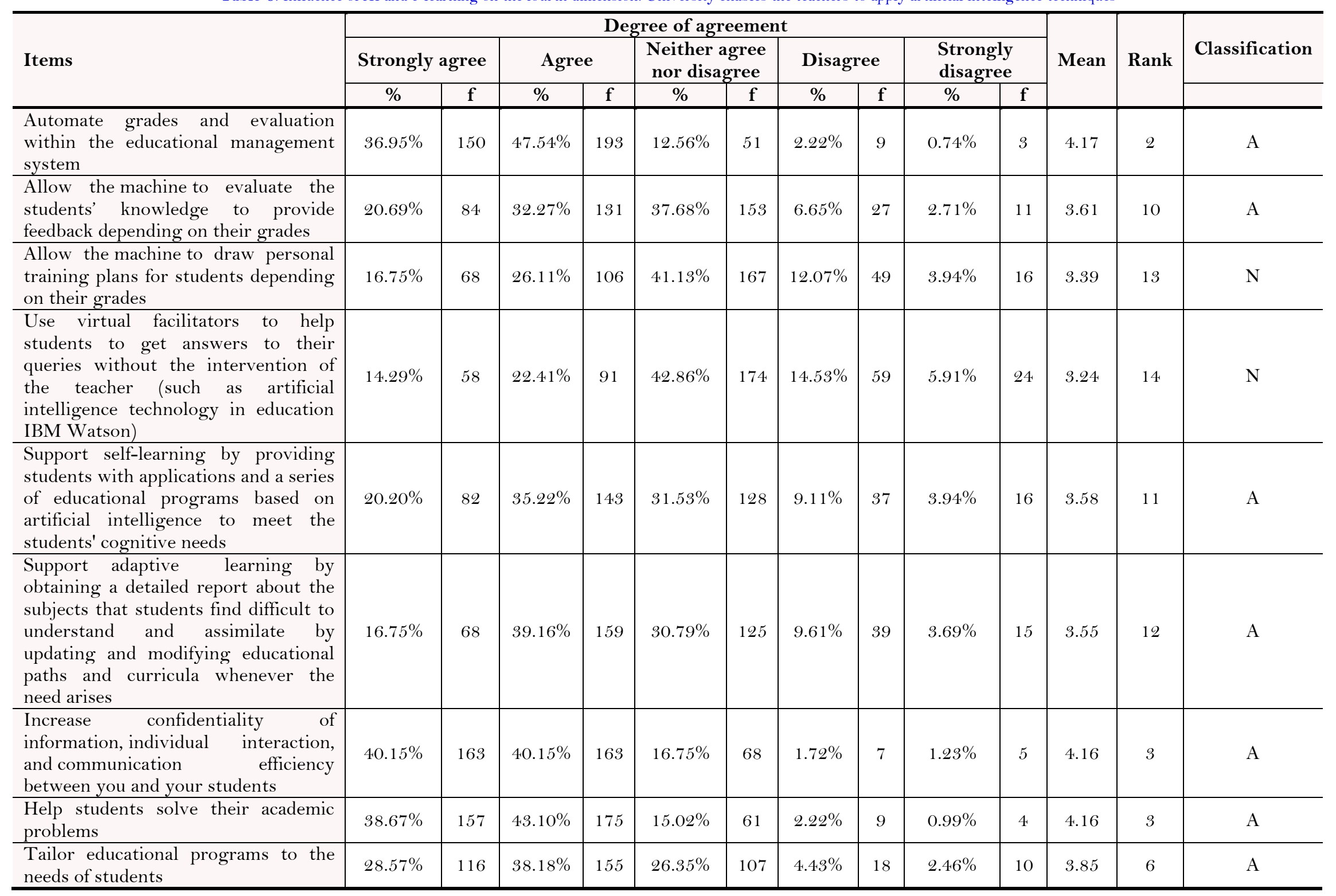


International Journal of Education and Practice, 2021, 9(4): 687-714

\begin{tabular}{|c|c|c|c|c|c|c|c|c|c|c|c|c|c|}
\hline $\begin{array}{l}\text { Help your students to indicate where } \\
\text { they need improvement in } \\
\text { coursework }\end{array}$ & $36.45 \%$ & 148 & $40.89 \%$ & 166 & $17.98 \%$ & 73 & $2.96 \%$ & 12 & $1.72 \%$ & 7 & 4.07 & 5 & A \\
\hline $\begin{array}{l}\text { Help students to access information } \\
\text { easily }\end{array}$ & $41.63 \%$ & 169 & $42.12 \%$ & 171 & $13.79 \%$ & 56 & $1.48 \%$ & 6 & $0.99 \%$ & 4 & 4.21 & 1 & $\mathrm{SA}$ \\
\hline $\begin{array}{l}\text { Use virtual mentoring to track } \\
\text { learners progress }\end{array}$ & $23.65 \%$ & 96 & $38.18 \%$ & 155 & $28.82 \%$ & 117 & $5.67 \%$ & 23 & $3.69 \%$ & 15 & 3.72 & 8 & A \\
\hline $\begin{array}{l}\text { Examine your students' knowledge } \\
\text { using electronic exams }\end{array}$ & $37.68 \%$ & 153 & $43.84 \%$ & 178 & $14.29 \%$ & 58 & $2.46 \%$ & 10 & $1.72 \%$ & 7 & 4.13 & 4 & A \\
\hline $\begin{array}{l}\text { Use rubrics scoring tool to evaluate } \\
\text { graded work }\end{array}$ & $28.57 \%$ & 116 & $37.93 \%$ & 154 & $23.65 \%$ & 96 & $4.93 \%$ & 20 & $4.93 \%$ & 20 & 3.80 & 7 & A \\
\hline $\begin{array}{l}\text { Use smart content that allows you to } \\
\text { provide your students with a digitized } \\
\text { textbook and customized interfaces. }\end{array}$ & $24.88 \%$ & 101 & $35.71 \%$ & 145 & $29.06 \%$ & 118 & $5.67 \%$ & 23 & $4.68 \%$ & 19 & 3.70 & 9 & A \\
\hline $\begin{array}{l}\text { Improve your teaching experience } \\
\text { during the virtual class by sending a } \\
\text { notification if you are speaking too } \\
\text { fast or too slow. }\end{array}$ & $19.21 \%$ & 78 & $24.88 \%$ & 101 & $34.24 \%$ & 139 & $10.34 \%$ & 42 & $11.33 \%$ & 46 & 3.30 & 15 & $\mathrm{~N}$ \\
\hline $\begin{array}{l}\text { Allow ChatBot to answer students' } \\
\text { questions regarding the lessons or } \\
\text { any question generally }\end{array}$ & $15.76 \%$ & 64 & $20.20 \%$ & 82 & $35.22 \%$ & 143 & $14.78 \%$ & 60 & $14.04 \%$ & 57 & 3.08 & 16 & $\mathrm{~N}$ \\
\hline Dimension mean & & & & & & & & & & & \multicolumn{2}{|c|}{3.74} & A \\
\hline
\end{tabular}

Note: SA: strongly agree; A: agree; N: Neither agree nor disagree 


\subsection{Impact of Age}

Since the age of the participants in a study can be an essential factor influencing the overall results, this research used the analysis of variance (ANOVA) test to find the differences among the responses of the faculty members with respect to their age Table 9.

Table-9. Results of ANOVA test regarding ages of the participants.

\begin{tabular}{|c|c|c|c|c|c|c|}
\hline Dimension & Variance source & Sum of Squares & df & Mean Square & $\mathbf{F}$ & Sig. \\
\hline \multirow{3}{*}{$\begin{array}{l}\text { The lecture aims related } \\
\text { practices during the pandemic }\end{array}$} & Between Groups & 83.482 & 3 & 27.827 & \multirow{3}{*}{1.630} & \multirow{3}{*}{0.18} \\
\hline & Within Groups & 6860.915 & 402 & 17.067 & & \\
\hline & Total & 6944.397 & 405 & & & \\
\hline \multirow{3}{*}{$\begin{array}{l}\text { Practices related to teaching } \\
\text { methods during the pandemic }\end{array}$} & Between Groups & 55.371 & 3 & 18.457 & \multirow{3}{*}{0.963} & \multirow{3}{*}{0.410} \\
\hline & Within Groups & 7705.567 & 402 & 19.168 & & \\
\hline & Total & 7760.938 & 405 & & & \\
\hline \multirow{3}{*}{$\begin{array}{l}\text { The faculty members practices } \\
\text { in general during the pandemic }\end{array}$} & Between Groups & 242.985 & 3 & 80.995 & \multirow{3}{*}{3.295} & \multirow{3}{*}{0.021} \\
\hline & Within Groups & 9880.269 & 402 & 24.578 & & \\
\hline & Total & 10123.254 & 405 & & & \\
\hline \multirow{3}{*}{$\begin{array}{l}\text { University enables you to } \\
\text { apply artificial intelligence } \\
\text { techniques }\end{array}$} & Between Groups & 904.927 & 3 & 301.642 & \multirow{3}{*}{2.021} & \multirow{3}{*}{0.110} \\
\hline & Within Groups & 60014.846 & 402 & 149.291 & & \\
\hline & Total & 60919.773 & 405 & & & \\
\hline \multirow{3}{*}{ total } & Between Groups & 3483.750 & 3 & 1161.250 & \multirow{3}{*}{2.652} & \multirow{3}{*}{0.058} \\
\hline & Within Groups & 176041.799 & 402 & 437.915 & & \\
\hline & Total & 179525.549 & 405 & & & \\
\hline
\end{tabular}

It was found that the factor of age exhibited significant differences only in one dimension viz. the faculty members' practices in general during the pandemic $(\mathrm{f}=3.29, \alpha \leq 0.05)$ while other dimensions did not depict significant differences $(\alpha>0.05)$. Further, post hoc analysis was conducted by LSD test, as shown in Table 10.

Table-10. Results of LSD test for differences among the age groups.

\begin{tabular}{|c|c|c|c|c|}
\hline Dependent Variable & Category 1 & Category2 & Mean Difference (I-J) & Sig. \\
\hline \multirow{12}{*}{$\begin{array}{l}\text { The faculty members practices in } \\
\text { general during the pandemic }\end{array}$} & \multirow{3}{*}{$20-30$} & $31-40$ & $-3.12801^{*}$ & 0.004 \\
\hline & & $41-50$ & $-3.34848^{*}$ & 0.002 \\
\hline & & $51+$ & $-2.59524^{*}$ & 0.032 \\
\hline & \multirow{3}{*}{$31-40$} & $20-30$ & $3.12801^{*}$ & 0.004 \\
\hline & & $41-50$ & -0.22048 & 0.694 \\
\hline & & $51+$ & 0.53277 & 0.479 \\
\hline & \multirow{3}{*}{$41-50$} & $20-30$ & $3.34848^{*}$ & 0.002 \\
\hline & & $31-40$ & 0.22048 & 0.694 \\
\hline & & $51+$ & 0.75325 & 0.341 \\
\hline & \multirow{3}{*}{$51+$} & $20-30$ & $2.59524^{*}$ & 0.032 \\
\hline & & $31-40$ & -0.53277 & 0.479 \\
\hline & & $41-50$ & -0.75325 & 0.341 \\
\hline
\end{tabular}

Our results indicated that the faculty members whose ages range from 20-30 years have less practice in general during the pandemic than others whose ages ranged from (31-51+).

\subsection{Differences According to the Nationality}

The independence t-test was used to find the differences among faculty members according to nationality Table 11. 
Table-11. Results of t-test regarding the nationality of the participants.

\begin{tabular}{|c|c|c|c|c|c|c|}
\hline Dimension & Nationality & $\mathbf{N}$ & Mean & Std. Deviation & $\mathrm{t}$ & $\operatorname{sig}$ \\
\hline \multirow{2}{*}{$\begin{array}{l}\text { The lecture aims related } \\
\text { practices during the pandemic }\end{array}$} & Saudi & 271 & 33.4280 & 4.16971 & \multirow{2}{*}{-2.65} & \multirow{2}{*}{0.008} \\
\hline & non-Saudi & 135 & 34.5778 & 3.98779 & & \\
\hline \multirow{2}{*}{$\begin{array}{l}\text { Practices related to teaching } \\
\text { methods during the pandemic }\end{array}$} & Saudi & 271 & 32.5720 & 4.47145 & \multirow{2}{*}{-2.73} & \multirow{2}{*}{0.007} \\
\hline & non-Saudi & 135 & 33.8222 & 4.07187 & & \\
\hline \multirow{2}{*}{$\begin{array}{l}\text { The faculty members practices } \\
\text { in general during the pandemic }\end{array}$} & Saudi & 271 & 49.2177 & 5.06263 & \multirow{2}{*}{-1.75} & \multirow{2}{*}{0.085} \\
\hline & non-Saudi & 135 & 50.1407 & 4.83020 & & \\
\hline \multirow{2}{*}{$\begin{array}{l}\text { University enables you to apply } \\
\text { artificial intelligence techniques }\end{array}$} & Saudi & 271 & 61.8376 & 12.93013 & \multirow{2}{*}{-5.18} & \multirow{2}{*}{0.000} \\
\hline & non-Saudi & 135 & 67.7778 & 9.69664 & & \\
\hline \multirow{2}{*}{ total } & Saudi & 271 & 177.0554 & 21.40891 & \multirow{2}{*}{-4.26} & \multirow{2}{*}{0.000} \\
\hline & non-Saudi & 135 & 186.3185 & 18.93455 & & \\
\hline
\end{tabular}

The results depicted significant differences in all dimensions $(\alpha \leq 0.05)$ except the dimension of the faculty members' practices in general during the pandemic. All of the differences related to the non-Saudi faculty members.

\subsection{Differences According to the Level of Education}

The influence of education on shaping responses of the participants was also investigated. ANOVA test was used to find the significant differences among the faculty members' responses (Table 12). The results indicated no significant differences in all dimensions concerning this factor $(\alpha>0.05)$.

Table-12. Influence of the level of education.

\begin{tabular}{|c|c|c|c|c|c|c|}
\hline Dimension & Variance source & $\begin{array}{c}\text { Sum of } \\
\text { Squares }\end{array}$ & df & $\begin{array}{c}\text { Mean } \\
\text { Square }\end{array}$ & $\mathbf{F}$ & Sig. \\
\hline \multirow{3}{*}{$\begin{array}{l}\text { The lecture aims related practices } \\
\text { during the pandemic }\end{array}$} & Between Groups & 32.852 & 4 & 8.213 & \multirow{3}{*}{0.477} & \multirow{3}{*}{0.753} \\
\hline & Within Groups & 6911.545 & 401 & 17.236 & & \\
\hline & Total & 6944.397 & 405 & & & \\
\hline \multirow{3}{*}{$\begin{array}{l}\text { Practices related to teaching } \\
\text { methods during the pandemic }\end{array}$} & Between Groups & 49.067 & 4 & 12.267 & \multirow{3}{*}{0.638} & \multirow{3}{*}{0.636} \\
\hline & Within Groups & 7711.872 & 401 & 19.232 & & \\
\hline & Total & 7760.938 & 405 & & & \\
\hline \multirow{3}{*}{$\begin{array}{l}\text { The faculty members practices in } \\
\text { general during the pandemic }\end{array}$} & Between Groups & 204.577 & 4 & 51.144 & \multirow{3}{*}{2.068} & \multirow{3}{*}{0.084} \\
\hline & Within Groups & 9918.676 & 401 & 24.735 & & \\
\hline & Total & 10123.254 & 405 & & & \\
\hline \multirow{3}{*}{$\begin{array}{l}\text { University enables you to apply } \\
\text { artificial intelligence techniques }\end{array}$} & Between Groups & 918.999 & 4 & 229.750 & \multirow{3}{*}{1.535} & \multirow{3}{*}{0.191} \\
\hline & Within Groups & 60000.774 & 401 & 149.628 & & \\
\hline & Total & 60919.773 & 405 & & & \\
\hline \multirow{3}{*}{ total } & Between Groups & 2430.696 & 4 & 607.674 & \multirow{3}{*}{1.376} & \multirow{3}{*}{0.241} \\
\hline & Within Groups & 177094.853 & 401 & 441.633 & & \\
\hline & Total & 179525.549 & 405 & & & \\
\hline
\end{tabular}

\subsection{Differences According to Teaching Experience in Traditional Learning}

Further, the impact of teaching experience in traditional learning was also investigated on the use of e-learning and AI (Table 13).

The significant differences were found only in dimension relating to the faculty members' practices in general during the pandemic for which the $\mathrm{f}=4.68$ and $\alpha \leq 0.01$, whereas the $\mathrm{f}$ values of all other dimensions had no significant degree $(\alpha>0.05)$. Next, a post hoc analysis was carried out by LSD test Table 14 .

The results indicated that the faculty members having less than one year of experience in traditional learning had less practice in general during the pandemic than the other groups who had 1- 3 years and more than three years of the traditional learning experience. 


\subsection{Differences According to Teaching Experience in E-Learning}

The influence of teaching experience in e-learning was also examined. For this purpose, the current study used the ANOVA test to find the differences among faculty members according to the teaching experience in e-learning Table 15.

Table-13. Results of ANOVA test regarding teaching experience in traditional learning.

\begin{tabular}{|c|c|c|c|c|c|c|}
\hline Dimension & Variance source & Sum of Squares & df & Mean Square & $\mathbf{F}$ & Sig. \\
\hline \multirow{3}{*}{$\begin{array}{l}\text { The lecture aims } \\
\text { related practices } \\
\text { during } \\
\text { pandemic }\end{array}$} & Between Groups & 33.297 & 2 & 16.648 & \multirow{3}{*}{0.971} & \multirow{3}{*}{0.380} \\
\hline & Within Groups & 6911.100 & 403 & 17.149 & & \\
\hline & Total & 6944.397 & 405 & & & \\
\hline \multirow{3}{*}{$\begin{array}{l}\text { Practices related to } \\
\text { teaching methods } \\
\text { during } \\
\text { pandemic }\end{array}$} & Between Groups & 7.044 & 2 & 3.522 & \multirow{3}{*}{ O. 183} & \multirow{3}{*}{0.833} \\
\hline & Within Groups & 7753.895 & 403 & 19.240 & & \\
\hline & Total & 7760.938 & 405 & & & \\
\hline \multirow{3}{*}{$\begin{array}{l}\text { The faculty } \\
\text { members practices } \\
\text { in general during } \\
\text { the pandemic }\end{array}$} & Between Groups & 229.903 & 2 & 114.952 & \multirow{3}{*}{4.682} & \multirow{3}{*}{0.010} \\
\hline & Within Groups & 9893.350 & 403 & 24.549 & & \\
\hline & Total & 10123.254 & 405 & & & \\
\hline \multirow{3}{*}{$\begin{array}{l}\text { University enables } \\
\text { you to apply } \\
\text { artificial } \\
\text { intelligence } \\
\text { techniques }\end{array}$} & Between Groups & 253.146 & 2 & 126.573 & \multirow{3}{*}{0.841} & \multirow{3}{*}{0.432} \\
\hline & Within Groups & 60666.627 & 403 & 150.538 & & \\
\hline & Total & 60919.773 & 405 & & & \\
\hline \multirow[t]{3}{*}{ total } & Between Groups & 958.321 & 2 & 479.161 & \multirow{3}{*}{1.081} & \multirow{3}{*}{0.340} \\
\hline & Within Groups & 178567.228 & 403 & 443.095 & & \\
\hline & Total & 179525.549 & 405 & & & \\
\hline
\end{tabular}

Table-14. Results of LSD test for faculty members' practices in general during the pandemic.

\begin{tabular}{|c|c|c|c|c|}
\hline Dimension & Category 1 & Category 2 & Mean Difference (I-J) & Sig. \\
\hline \multirow{6}{*}{$\begin{array}{l}\text { The faculty members practices } \\
\text { in general during the pandemic }\end{array}$} & \multirow{2}{*}{$\begin{array}{l}\text { Less than one } \\
\text { year }\end{array}$} & From 1 to 3 years & $-2.53184^{*}$ & 0.010 \\
\hline & & More than 3 years & $-2.59628^{*}$ & 0.003 \\
\hline & \multirow{2}{*}{ From 1 to 3 years } & Less than one year & $2.53184^{*}$ & 0.010 \\
\hline & & More than 3 years & -0.06444 & 0.918 \\
\hline & \multirow{2}{*}{$\begin{array}{c}\text { More than } 3 \\
\text { years }\end{array}$} & Less than one year & $2.59628^{*}$ & 0.003 \\
\hline & & From 1 to 3 years & 0.06444 & 0.918 \\
\hline
\end{tabular}

Table-15. Results of ANOVA test regarding the influence of teaching experience in e-learning.

\begin{tabular}{|c|c|c|c|c|c|c|}
\hline Dimension & $\begin{array}{l}\text { Variance } \\
\text { source }\end{array}$ & Sum of Squares & df & Mean Square & $\mathbf{F}$ & Sig. \\
\hline \multirow{3}{*}{$\begin{array}{l}\text { The lecture aims related } \\
\text { practices during the } \\
\text { pandemic }\end{array}$} & Between Groups & 132.676 & 2 & 66.338 & \multirow{3}{*}{3.925} & \multirow{3}{*}{0.021} \\
\hline & Within Groups & 6811.721 & 403 & 16.903 & & \\
\hline & Total & 6944.397 & 405 & & & \\
\hline \multirow{3}{*}{$\begin{array}{l}\text { Practices related to } \\
\text { teaching methods during } \\
\text { the pandemic }\end{array}$} & Between Groups & 291.774 & 2 & 145.887 & \multirow{3}{*}{7.871} & \multirow{3}{*}{0.000} \\
\hline & Within Groups & 7469.165 & 403 & 18.534 & & \\
\hline & Total & 7760.938 & 405 & & & \\
\hline \multirow{3}{*}{$\begin{array}{l}\text { The faculty members } \\
\text { practices in general during } \\
\text { the pandemic }\end{array}$} & Between Groups & 428.578 & 2 & 214.289 & \multirow{3}{*}{8.908} & \multirow{3}{*}{0.000} \\
\hline & Within Groups & 9694.676 & 403 & 24.056 & & \\
\hline & Total & 10123.254 & 405 & & & \\
\hline \multirow{3}{*}{$\begin{array}{l}\text { University enables you to } \\
\text { apply artificial intelligence } \\
\text { techniques }\end{array}$} & Between Groups & 4122.349 & 2 & 2061.175 & \multirow{3}{*}{14.625} & \multirow{3}{*}{0.000} \\
\hline & Within Groups & 56797.424 & 403 & 140.937 & & \\
\hline & Total & 60919.773 & 405 & & & \\
\hline \multirow{3}{*}{ total } & Between Groups & 12814.360 & 2 & 6407.180 & \multirow{3}{*}{15.488} & \multirow{3}{*}{0.000} \\
\hline & Within Groups & 166711.189 & 403 & 413.675 & & \\
\hline & Total & 179525.549 & 405 & & & \\
\hline
\end{tabular}


Significant differences were observed in all dimensions. Therefore, a post hoc analysis was conducted by LSD test Table 16.

Table-16. Results of LSD test for differences according to the experience in e-learning.

\begin{tabular}{|c|c|c|c|c|}
\hline Dependent Variable & Category 1 & Category 2 & $\begin{array}{l}\text { Mean Difference (I- } \\
\mathbf{J})\end{array}$ & Sig. \\
\hline \multirow{6}{*}{$\begin{array}{l}\text { The lecture aims related } \\
\text { practices during the pandemic }\end{array}$} & \multirow{2}{*}{ Less than one year } & From 1 to 3 years & $-1.04922^{*}$ & 0.038 \\
\hline & & More than 3 years & $-1.24446^{*}$ & 0.010 \\
\hline & \multirow{2}{*}{ From 1 to 3 years } & Less than one year & $1.04922^{*}$ & 0.038 \\
\hline & & More than 3 years & -0.19524 & 0.713 \\
\hline & \multirow{2}{*}{ More than 3 years } & Less than one year & $1.24446^{*}$ & 0.010 \\
\hline & & From 1 to 3 years & 0.19524 & 0.713 \\
\hline \multirow{6}{*}{$\begin{array}{l}\text { Practices related to teaching } \\
\text { methods during the pandemic }\end{array}$} & \multirow{2}{*}{ Less than one year } & From 1 to 3 years & $-1.43271^{*}$ & 0.007 \\
\hline & & More than 3 years & $-1.90379^{*}$ & 0.000 \\
\hline & \multirow{2}{*}{ From 1 to 3 years } & Less than one year & $1.43271^{*}$ & 0.007 \\
\hline & & More than 3 years & -0.47108 & 0.397 \\
\hline & \multirow{2}{*}{ More than 3 years } & Less than one year & $1.90379^{*}$ & 0.000 \\
\hline & & From 1 to 3 years & 0.47108 & 0.397 \\
\hline \multirow{6}{*}{$\begin{array}{l}\text { The faculty members practices } \\
\text { in general during the } \\
\text { pandemic }\end{array}$} & \multirow{2}{*}{ Less than one year } & From 1 to 3 years & $-1.74017^{*}$ & 0.004 \\
\hline & & More than 3 years & $-2.30581^{*}$ & 0.000 \\
\hline & \multirow{2}{*}{ From 1 to 3 years } & Less than one year & $1.74017^{*}$ & 0.004 \\
\hline & & More than 3 years & -0.56564 & 0.372 \\
\hline & \multirow{2}{*}{ More than 3 years } & Less than one year & $2.30581^{*}$ & 0.000 \\
\hline & & From 1 to 3 years & 0.56564 & 0.372 \\
\hline \multirow{6}{*}{$\begin{array}{l}\text { University enables you to } \\
\text { apply artificial intelligence } \\
\text { techniques }\end{array}$} & \multirow{2}{*}{ Less than one year } & From 1 to 3 years & $-4.65227^{*}$ & 0.002 \\
\hline & & More than 3 years & $-7.38345^{*}$ & 0.000 \\
\hline & \multirow{2}{*}{ From 1 to 3 years } & Less than one year & $4.65227^{*}$ & 0.002 \\
\hline & & More than 3 years & -2.73117 & 0.075 \\
\hline & \multirow{2}{*}{ More than 3 years } & Less than one year & $7.38345^{*}$ & 0.000 \\
\hline & & From 1 to 3 years & 2.73117 & 0.075 \\
\hline \multirow{6}{*}{ total } & \multirow{2}{*}{ Less than one year } & From 1 to 3 years & $-8.87437^{*}$ & 0.000 \\
\hline & & More than 3 years & $-12.83751^{*}$ & 0.000 \\
\hline & \multirow{2}{*}{ From 1 to 3 years } & Less than one year & $8.87437^{*}$ & 0.000 \\
\hline & & More than 3 years & -3.96314 & 0.132 \\
\hline & \multirow{2}{*}{ More than 3 years } & Less than one year & $12.83751^{*}$ & 0.000 \\
\hline & & From 1 to 3 years & 3.96314 & 0.132 \\
\hline
\end{tabular}

In all dimensions, the members who had less than one year of experience in e-learning showed lesser degrees and smaller total degrees compared with the other categories.

\subsection{Differences According to Experience in Using Artificial Intelligence Techniques}

The ANOVA test was employed to find the significant differences among faculty members according to their use of artificial intelligence techniques Table 17.

Significant differences were observed in all the dimensions, as evident from f values at the level of significance $\alpha$ $\leq$ 0.05. Subsequently, a post hoc analysis was performed using the LSD test Table 18 .

In the first dimension (the lecture aims related practices during the pandemic), there were significant differences among the participants who had less than one year of experience compared with those who had more than three years of experience in artificial intelligence techniques. In the second dimension (practices related to teaching methods during the pandemic), there was a significant difference between the respondents who had less than one year of experience compared with those having 1-3 years as well as more than three years of experience in using artificial intelligence techniques. 
Table-17. Results of ANOVA test regarding the influence of the experience of respondents in using artificial intelligence techniques.

\begin{tabular}{|c|c|c|c|c|c|c|}
\hline Dimensions & $\begin{array}{c}\text { Variance } \\
\text { source } \\
\end{array}$ & Sum of Squares & df & $\begin{array}{c}\text { Mean } \\
\text { Square }\end{array}$ & $\mathbf{F}$ & Sig. \\
\hline \multirow{3}{*}{$\begin{array}{l}\text { The lecture aims } \\
\text { related practices during } \\
\text { the pandemic }\end{array}$} & Between Groups & 163.765 & 2 & 81.883 & \multirow{3}{*}{4.867} & \multirow{3}{*}{0.008} \\
\hline & Within Groups & 6780.631 & 403 & 16.825 & & \\
\hline & Total & 6944.397 & 405 & & & \\
\hline \multirow{3}{*}{$\begin{array}{l}\text { Practices related to } \\
\text { teaching } \\
\text { during the pandemic }\end{array}$} & Between Groups & 351.347 & 2 & 175.674 & \multirow{3}{*}{9.555} & \multirow{3}{*}{0.000} \\
\hline & Within Groups & 7409.591 & 403 & 18.386 & & \\
\hline & Total & 7760.938 & 405 & & & \\
\hline \multirow{3}{*}{$\begin{array}{l}\text { The faculty members } \\
\text { practices in general } \\
\text { during the pandemic }\end{array}$} & Between Groups & 368.627 & 2 & 184.313 & \multirow{3}{*}{7.615} & \multirow{3}{*}{0.001} \\
\hline & Within Groups & 9754.627 & 403 & 24.205 & & \\
\hline & Total & 10123.254 & 405 & & & \\
\hline \multirow{3}{*}{$\begin{array}{l}\text { University enables you } \\
\text { to apply artificial } \\
\text { intelligence techniques }\end{array}$} & Between Groups & 5459.972 & 2 & 2729.986 & \multirow{3}{*}{19.838} & \multirow{3}{*}{0.000} \\
\hline & Within Groups & 55459.802 & 403 & 137.617 & & \\
\hline & Total & 60919.773 & 405 & & & \\
\hline \multirow{3}{*}{ total } & Between Groups & 15460.076 & 2 & 7730.038 & \multirow{3}{*}{18.988} & \multirow{3}{*}{0.000} \\
\hline & Within Groups & 164065.474 & 403 & 407.110 & & \\
\hline & Total & 179525.549 & 405 & & & \\
\hline
\end{tabular}

Table-18. Results of LSD test for differences with respect to the experience of the respondents in using artificial intelligence techniques.

\begin{tabular}{|c|c|c|c|c|}
\hline Dependent Variable & Category 1 & Category 2 & Mean Difference (I-J) & Sig. \\
\hline \multirow{6}{*}{$\begin{array}{l}\text { The lecture aims related } \\
\text { practices during the pandemic }\end{array}$} & \multirow{2}{*}{ Less than one year } & From 1 to 3 years & -0.87974 & 0.071 \\
\hline & & More than 3 years & $-1.63814^{*}$ & 0.004 \\
\hline & \multirow{2}{*}{ From 1 to 3 years } & Less than one year & 0.87974 & 0.071 \\
\hline & & More than 3 years & -.75839 & 0.233 \\
\hline & \multirow{2}{*}{ More than 3 years } & Less than one year & $1.63814^{*}$ & 0.004 \\
\hline & & From 1 to 3 years & 0.75839 & 0.233 \\
\hline \multirow{6}{*}{$\begin{array}{l}\text { Practices related to teaching } \\
\text { methods during the pandemic }\end{array}$} & \multirow{2}{*}{ Less than one year } & From 1 to 3 years & $-1.50385^{*}$ & 0.003 \\
\hline & & More than 3 years & $-2.27112^{*}$ & 0.000 \\
\hline & \multirow{2}{*}{ From 1 to 3 years } & Less than one year & $1.50385^{*}$ & 0.003 \\
\hline & & More than 3 years & -0.76727 & 0.249 \\
\hline & \multirow{2}{*}{ More than 3 years } & Less than one year & $2.27112^{*}$ & 0.000 \\
\hline & & From 1 to 3 years & 0.76727 & 0.249 \\
\hline \multirow{6}{*}{$\begin{array}{l}\text { The faculty members practices } \\
\text { in general during the } \\
\text { pandemic }\end{array}$} & \multirow{2}{*}{ Less than one year } & From 1 to 3 years & $-1.68132^{*}$ & 0.004 \\
\hline & & More than 3 years & $-2.21183^{*}$ & 0.001 \\
\hline & \multirow{2}{*}{ From 1 to 3 years } & Less than one year & $1.68132^{*}$ & 0.004 \\
\hline & & More than 3 years & -0.53051 & 0.487 \\
\hline & \multirow{2}{*}{ More than 3 years } & Less than one year & $2.21183^{*}$ & 0.001 \\
\hline & & From 1 to 3 years & 0.53051 & 0.487 \\
\hline \multirow{6}{*}{$\begin{array}{l}\text { University enables you to } \\
\text { apply artificial intelligence } \\
\text { techniques }\end{array}$} & \multirow{2}{*}{ Less than one year } & From 1 to 3 years & $-5.34439^{*}$ & 0.000 \\
\hline & & More than 3 years & $-9.32164^{*}$ & 0.000 \\
\hline & \multirow{2}{*}{ From 1 to 3 years } & Less than one year & $5.34439^{*}$ & 0.000 \\
\hline & & More than 3 years & $-3.97725^{*}$ & 0.029 \\
\hline & \multirow{2}{*}{ More than 3 years } & Less than one year & $9.32164^{*}$ & 0.000 \\
\hline & & From 1 to 3 years & $3.97725^{*}$ & 0.029 \\
\hline \multirow{6}{*}{ total } & \multirow{2}{*}{ Less than one year } & From 1 to 3 years & $-9.40931^{*}$ & 0.000 \\
\hline & & More than 3 years & $-15.44273^{*}$ & 0.000 \\
\hline & \multirow{2}{*}{ From 1 to 3 years } & Less than one year & $9.40931^{*}$ & 0.000 \\
\hline & & More than 3 years & -6.03343 & 0.054 \\
\hline & \multirow{2}{*}{ More than 3 years } & Less than one year & $15.44273^{*}$ & 0.000 \\
\hline & & From 1 to 3 years & 6.03343 & 0.054 \\
\hline
\end{tabular}

Likewise, the third dimension (faculty members' practices in general during the pandemic) also produced similar results, and significant differences were observed among less than one year, 1-3 years, and more than three years' groups. In the fourth dimension, it was evident that the entrants who had greater experience in the use of artificial intelligence techniques exhibited more degrees than those with lesser experience (less than one year and from 1-3 years). 
Table-19. Results of ANOVA test regarding the influence of using e-learning and artificial intelligence techniques in teaching before the COVID-19 pandemic.

\begin{tabular}{|c|c|c|c|c|c|c|}
\hline Dimension & Variance source & $\begin{array}{l}\text { Sum of } \\
\text { Squares }\end{array}$ & df & $\begin{array}{c}\text { Mean } \\
\text { Square }\end{array}$ & $\mathbf{F}$ & Sig. \\
\hline \multirow{3}{*}{$\begin{array}{l}\text { The lecture aims related } \\
\text { practices during the } \\
\text { pandemic }\end{array}$} & Between Groups & 320.254 & 2 & 160.127 & \multirow{3}{*}{9.742} & \multirow{3}{*}{0.000} \\
\hline & Within Groups & 6624.142 & 403 & 16.437 & & \\
\hline & Total & 6944.397 & 405 & & & \\
\hline \multirow{3}{*}{$\begin{array}{l}\text { Practices related to } \\
\text { teaching methods during } \\
\text { the pandemic }\end{array}$} & Between Groups & 707.771 & 2 & 353.886 & \multirow{3}{*}{20.220} & \multirow{3}{*}{0.000} \\
\hline & Within Groups & 7053.167 & 403 & 17.502 & & \\
\hline & Total & 7760.938 & 405 & & & \\
\hline \multirow{3}{*}{$\begin{array}{l}\text { The faculty members } \\
\text { practices in general } \\
\text { during the pandemic }\end{array}$} & Between Groups & 742.252 & 2 & 371.126 & \multirow{3}{*}{15.943} & \multirow{3}{*}{0.000} \\
\hline & Within Groups & 9381.002 & 403 & 23.278 & & \\
\hline & Total & 10123.254 & 405 & & & \\
\hline \multirow{3}{*}{$\begin{array}{l}\text { University enables you } \\
\text { to apply artificial } \\
\text { intelligence techniques }\end{array}$} & Between Groups & 6756.494 & 2 & 3378.247 & \multirow{3}{*}{25.136} & \multirow{3}{*}{0.000} \\
\hline & Within Groups & 54163.279 & 403 & 134.400 & & \\
\hline & Total & 60919.773 & 405 & & & \\
\hline \multirow{3}{*}{ total } & Between Groups & 23011.052 & 2 & 11505.526 & \multirow{3}{*}{29.625} & \multirow{3}{*}{0.000} \\
\hline & Within Groups & 156514.479 & 403 & 388.373 & & \\
\hline & Total & 179525.549 & 405 & & & \\
\hline
\end{tabular}

Table-20. Results of LSD test for differences with respect to using e-learning and artificial intelligence techniques in teaching before COVID-19 pandemic.

\begin{tabular}{|c|c|c|c|c|}
\hline Dependent Variable & Category 1 & Category 2 & Mean Difference (I-J) & Sig. \\
\hline \multirow{6}{*}{$\begin{array}{l}\text { The lecture aims related practices during the } \\
\text { pandemic } \\
\text { Practices related to teaching methods during } \\
\text { the pandemic }\end{array}$} & \multirow{2}{*}{ never } & sometimes & $-1.45937^{*}$ & 0.003 \\
\hline & & Always & $-2.17202^{*}$ & 0.000 \\
\hline & \multirow{2}{*}{ sometimes } & never & $1.45937^{*}$ & 0.003 \\
\hline & & Always & -0.71265 & 0.147 \\
\hline & \multirow{2}{*}{ Always } & never & $2.17202^{*}$ & 0.000 \\
\hline & & sometimes & 0.71265 & 0.147 \\
\hline \multirow{6}{*}{$\begin{array}{l}\text { The faculty members practices in general } \\
\text { during the pandemic } \\
\text { University enables you to apply artificial } \\
\text { intelligence techniques }\end{array}$} & \multirow{2}{*}{ never } & sometimes & $-2.75928^{*}$ & 0.000 \\
\hline & & Always & $-2.89266^{*}$ & 0.000 \\
\hline & \multirow{2}{*}{ sometimes } & never & $2.75928^{*}$ & 0.000 \\
\hline & & Always & -0.13398 & 0.792 \\
\hline & \multirow{2}{*}{ Always } & never & $2.89266^{*}$ & 0.000 \\
\hline & & sometimes & 0.13338 & 0.792 \\
\hline \multirow{6}{*}{$\begin{array}{l}\text { The lecture aims related practices during the } \\
\text { pandemic } \\
\text { Practices related to teaching methods during } \\
\text { the pandemic }\end{array}$} & \multirow{2}{*}{ never } & sometimes & $-1.47360^{*}$ & 0.012 \\
\hline & & Always & $-3.37091^{*}$ & 0.000 \\
\hline & \multirow[b]{2}{*}{ sometimes } & never & $1.47360^{*}$ & 0.012 \\
\hline & & Always & $-1.89731^{*}$ & 0.001 \\
\hline & \multirow{2}{*}{ Always } & never & $3.37091^{*}$ & 0.000 \\
\hline & & sometimes & $1.89731^{*}$ & 0.001 \\
\hline \multirow{6}{*}{$\begin{array}{l}\text { The faculty members practices in general } \\
\text { during the pandemic }\end{array}$} & \multirow{2}{*}{ never } & sometimes & $-7.10996^{*}$ & 0.000 \\
\hline & & Always & $-9.83922^{*}$ & 0.000 \\
\hline & \multirow{2}{*}{ sometimes } & never & $7.10996^{*}$ & 0.000 \\
\hline & & Always & -2.72927 & 0.052 \\
\hline & \multirow{2}{*}{ Always } & never & $9.83922^{*}$ & 0.000 \\
\hline & & sometimes & 2.72927 & 0.052 \\
\hline \multirow{6}{*}{ total } & \multirow{2}{*}{ never } & sometimes & $-12.80221^{*}$ & 0.000 \\
\hline & & Always & $-18.27481^{*}$ & 0.000 \\
\hline & \multirow{2}{*}{ sometimes } & never & $12.80221^{*}$ & 0.000 \\
\hline & & Always & $-5.47260^{*}$ & 0.022 \\
\hline & \multirow{2}{*}{ Always } & never & $18.27481^{*}$ & 0.000 \\
\hline & & sometimes & $5.47260^{*}$ & 0.022 \\
\hline
\end{tabular}

Hence, the respondents having 1-3 years of experience demonstrated more degrees than those with less than one year of experience in using artificial intelligence techniques. Overall, the greater experience in the use of AI techniques produced comparatively higher values. 
7.16. Differences According to Using E-learning and Artificial Intelligence Techniques in Teaching before the COVID-19 Pandemic

The ANOVA test was used to find the differences among faculty members according to their experience of using e-learning and artificial intelligence techniques in teaching before the COVID-19 pandemic. The results of this analysis are presented in Table 19.

Significant differences were noticed in all dimensions $(\alpha \leq 0.05)$. Next, a post hoc analysis was conducted using the LSD test Table 20.

The results of LSD analysis indicated that the respondents who had prior e-learning and artificial intelligence techniques use experience had more degrees in all dimensions.

\subsection{Differences Due to Type of Institution}

For assessing the effect of affiliation of the responders, the researcher considered the Saudi Electronic University as the first category and all other universities as the second category. Then, t-test was employed to find the significant differences (Table 21).

Table-21. Results of t-test regarding the influence of the type of the university.

\begin{tabular}{|c|c|c|c|c|c|c|}
\hline Dimension & Type of university & $\mathbf{N}$ & Mean & Std. Deviation & $\mathrm{t}$ & Sig. \\
\hline \multirow{2}{*}{$\begin{array}{l}\text { The lecture aims } \\
\text { related practices } \\
\text { during the pandemic }\end{array}$} & Saudi Electronic University & 165 & 34.3333 & 4.09690 & \multirow{2}{*}{2.11} & \multirow{2}{*}{0.035} \\
\hline & other universities & 241 & 33.4523 & 4.14111 & & \\
\hline \multirow{2}{*}{$\begin{array}{l}\text { Practices related to } \\
\text { teaching methods } \\
\text { during the pandemic }\end{array}$} & Saudi Electronic University & 165 & 33.6727 & 4.22560 & \multirow{2}{*}{2.62} & \multirow{2}{*}{0.009} \\
\hline & other universities & 241 & 32.5187 & 4.42633 & & \\
\hline \multirow{2}{*}{$\begin{array}{l}\text { The faculty members } \\
\text { practices in general } \\
\text { during the pandemic }\end{array}$} & Saudi Electronic University & 165 & 50.6909 & 4.58739 & \multirow{2}{*}{3.95} & \multirow{2}{*}{0.000} \\
\hline & other universities & 241 & 48.7261 & 5.12100 & & \\
\hline \multirow{2}{*}{$\begin{array}{l}\text { University enables } \\
\text { you to apply artificial } \\
\text { intelligence } \\
\text { techniques }\end{array}$} & Saudi Electronic University & 165 & 67.0061 & 10.09135 & \multirow[b]{2}{*}{4.44} & \multirow[b]{2}{*}{0.000} \\
\hline & other universities & 241 & 61.6266 & 13.13145 & & \\
\hline \multirow{2}{*}{ total } & Saudi Electronic University & 165 & 185.7030 & 18.14146 & \multirow{2}{*}{4.51} & \multirow{2}{*}{0.000} \\
\hline & other universities & 241 & 176.3237 & 22.07325 & & \\
\hline
\end{tabular}

There was a significant difference between Saudi Electronic University and other universities in all dimensions ( $\mathrm{t}$ values had $\alpha<0.05$ ). This analysis showed that e-learning and AI techniques had a greater role in improving faculty members' behavior and practices in Saudi Electronic University compared with the other universities.

Table-22. Means of sample responses for the four fields of the study.

\begin{tabular}{|c|c|c|c|c|c|}
\hline \multicolumn{6}{|c|}{ Statistics } \\
\hline & & Practices during a pandemic & $\begin{array}{l}\text { Teaching } \\
\text { methods }\end{array}$ & $\begin{array}{l}\text { Faculty } \\
\text { member }\end{array}$ & $\begin{array}{c}\text { Artificial } \\
\text { intelligence }\end{array}$ \\
\hline \multirow{2}{*}{$\mathrm{N}$} & Valid & 406 & 406 & 406 & 406 \\
\hline & Missing & 1 & 1 & 1 & 1 \\
\hline \multicolumn{2}{|r|}{ Mean } & 4.2263 & 4.1239 & 4.5103 & 3.7537 \\
\hline \multicolumn{2}{|c|}{ Arrangement } & Assent & Assent & Strong approval & Assent \\
\hline
\end{tabular}

Further dissection of our data indicated that the average of the sample responses for the field of practices during the pandemic was equal to 4.2263, which corresponded to the degree of approval. While the average of the samples' responses for the field of teaching methods was 4.1239, which also corresponded to the degree of approval (Table 22). The highest average of the sample responses was noticed for the field "faculty members." The mean for 
this parameter was 4.5103, and it corresponded to the degree of strong approval. Similarly, the average of the sample answers for the field of artificial intelligence also corresponded to the degree of approval (3.7537).

\subsection{Hypothesis Testing}

Through the one-sample t-test, the hypothesis testing illustrated a significant effect (at the $\alpha \leq 0.05$ level) of AI techniques on improving the faculty members' practices during the pandemic (Table 23). Secondly, the AI techniques also depicted a statistically significant effect (at the $\alpha \leq 0.05$ ) on improving the practices related to teaching methods during the pandemic. Furthermore, the effect of AI techniques on improving faculty practices in general during the pandemic was also significant $(\alpha \leq 0.05)$.

Table-23. Results of hypotheses testing using one-sample t-test.

\begin{tabular}{c|c|c|c|c|c|c}
\hline \multirow{2}{*}{ Variables } & \multicolumn{7}{c}{ One-Sample Test } \\
\cline { 2 - 7 } & $T^{*}$ & Df* & $\begin{array}{c}\text { Tig. } \\
(2-t a i l e d)(\text { alpha) }\end{array}$ & $\begin{array}{c}\text { Mean } \\
\text { Difference }\end{array}$ & $\begin{array}{c}\text { 95\% Confidence Interval of the } \\
\text { Difference }\end{array}$ \\
\hline F1 & 47.737 & 405 & 0.000 & 1.22629 & 1.1758 & Upper \\
\hline F2 & 41.364 & 405 & 0.000 & 1.12394 & 1.0705 & 1.2768 \\
\hline F3 & 68.086 & 405 & 0.000 & 1.51031 & 1.4667 & 1.5539 \\
\hline F4 & 21.050 & 405 & 0.000 & 0.75369 & 0.6833 & 0.8241 \\
\hline Note: & & & & & & Uner \\
\hline
\end{tabular}

*DF: Degrees of freedom.

*T: T-test of the sample.

Sig $=(2$-tailed $)=($ alpha $)$.

F1: Practices during the pandemic

F2: Practices related to teaching methods during the pandemic.

F3: The faculty members' practices in general during the pandemic

F4: Application of artificial intelligence techniques.

\section{DISCUSSION}

The COVID-19 pandemic presented a unique challenge to the world in 2020. It was a year of lockdowns, social distancing, and masks. The deadly virus brought changes to every aspect of life. Likewise, the education sector was one of the badly hit areas by this pandemic worldwide (Toquero, 2020). Educational institutions were closed all over the world, leading to interruptions in conventional teaching. In this scenario, online education was adopted globally (Bozkurt \& Sharma, 2020). In many of the countries, Zoom, Microsoft Teams, and Google Meet dominated as tools for video conferencing and lecturing, while others opted for learning management systems such as Blackboard, Google Classroom, Edmodo, and Moodle (Layali \& Al-Shlowiy, 2020; Mukhtar., Javed, Arooj, \& Sethi, 2020b; Shahzad, Hassan, Aremu, Hussain, \& Lodhi, 2021). Similarly, in Saudi Arabia, the ministry of education instructed the education sector to suspend conventional schooling on $8^{\text {th }}$ March 2020, and the universities shifted to online means of education. Nevertheless, the adoption of online education presented new challenges both to the educators as well as students (Adedoyin \& Soykan, 2020). Keeping this background in view, the current study investigated the pedagogical perspective of e-learning in the time of the COVID-19 pandemic. Moreover, since artificial intelligence has become an essential component of e-learning (Zawacki-Richter, Marín, Bond, \& Gouverneur, 2019) its significance in improving online education was also examined. A total of 406 samples were collected from various universities in Saudi Arabia, and then an extensive exploration was done to investigate the lecture aims related practices, teaching methods related practices, and faculty members' practices in general and during the pandemic. Furthermore, the researcher also analyzed the influence of artificial intelligence techniques in improving e-learning. Finally, the impact of various factors such as age, nationality, level of education, and experience in traditional learning, e-learning and AI techniques was researched. Hence, this study carries 
paramount importance with respect to the current pandemic, online education, and use of AI techniques in elearning. The data of this study revealed that the age and teaching experience of the participants in conventional education significantly impacted the faculty members' practices in general during the pandemic. For non-Saudi faculty, the same dimension was significantly influenced by nationality as well, while the level of education did not show a significant effect. This observation could be attributed to the fact that the sampling population encompassed faculty members of academic institutions, and all of the participants were educated. Similar results were reported earlier by Tayyib et al. (2020) while studying e-learning in Saudi Arabia. The differences with respect to the prior teaching experience in e-learning and using AI techniques impacted all the dimensions significantly, indicating that the entrants who had used these tools earlier had appreciated and embraced them. This kind of former experience would have also increased the educators' readiness to use these techniques (Tayyib et al., 2020). In accordance with our results, Alqahtani and Rajkhan (2020) explored the educators at Saudi universities to determine the factors associated with the e-learning adoption and found that the knowledge of the implementation strategies was a critical component of e-learning success in the COVID-19 crisis. Our results revealed that teachers at Saudi Arabian universities were making extensive use of the e-learning management system Blackboard. The faculty members strongly agreed that e-learning and AI techniques improved relevant lecture aims related practices during the pandemic by facilitating in formulating educational goals, tailoring lecture plans, implementing lessons' objectives, and assisting in students' difficulties. Hence, the potential role of e-learning and AI techniques in Saudi Arabia in the wake of the current pandemic was evident. Various AI tools have been developed for teachers as well as students (Pedro, Subosa, Rivas, \& Valverde, 2019). These tools interact with the students and learn from their responses (Chassignol, Khoroshavin, Klimova, \& Bilyatdinova, 2018). Subsequently, data from these interactions help teachers assess students' difficulties and set educational goals accordingly (Crown, Fuentes, Jones, Nambiar, \& Crown, 2011). Duffy and Azevedo (2015) reported a tool called MetaTutor that aids students in accomplishing their academic targets. Artificial intelligence has also been applied to teach English as a second language, and it successfully remitted linguistic errors and improved the learning efficiency of students (Dodigovic, 2007).

The influence of e-learning and AI techniques on practices related to teaching methods during the pandemic was also highly positive, and the study population either strongly agreed or agreed to the questions in this dimension. The role of e-learning in providing novel teaching methods has been recognized for a while (Andrade, 2015; Gibson, 1983; Li, Qi, Wang, \& Wang, 2014). Parallel to our results, Mukhtar et al. (2020b) also mentioned that e-learning facilitates group discussions. Similarly, the role of intelligent tutoring in augmenting students' motivation has been established in previous studies (Duffy \& Azevedo, 2015). The students in a class exhibit individual differences and may have dissimilar needs (Durlach \& Lesgold, 2012). In conventional classrooms, it may be challenging to recognize and cater to each students' learning requirements. AI techniques builds students' performance profiles and develops models based on their knowledge and personal skills (Hussain, Zhu, Zhang, Abidi, \& Ali, 2019). This data can then be used to tweak the teaching methods and content and provide adaptive learning to students (Almohammadi, Hagras, Alghazzawi, \& Aldabbagh, 2017). In line with the former reports, the researcher observed the educators' agreement that e-learning and AI techniques helped them take into account the individual differences of learners. The flexibility of online education was another benefit that the study population consented to. The flexibility and better control of e-learning are not limited to teachers alone, but students also experience it Alqahtani and Rajkhan (2020); Layali and Al-Shlowiy (2020); Dhawan (2020). Many times, schedules can be adjusted, or recorded lectures are available for revising the content in online education (Mukhtar et al., 2020b). Thence, learners with busy schedules prefer online courses instead of traditional ones (Butcher \& RoseAdams, 2015). Another theme explored in this study related to the faculty members' practices in general during the pandemic. Here too, the educators strongly agreed that e-learning and AI techniques ameliorated their teaching practices. Our data depicted that online-learning made the teachers' experience exciting. Online education, in fact, goes beyond than just a learning tool (Paudel, 2020). Similar reports have emerged from the educators' responses 
from other countries also (Arslan, 2015; Finlayson, Maxwell, Caillau, \& Tomalin, 2006). The instructors handle students with more respect, raise their confidence, and promote conversations when they are more interested in eteaching. All of these parameters are related to "effective online teaching" (Frazer, Sullivan, Weatherspoon, \& Hussey, 2017; Sun \& Chen, 2016). Hence, it could be speculated that most of our responders were using effective teaching strategies. Regarding learners' perspectives, Arslan (2015) suggested that students also appreciated the online education and AI experience. Moreover, the entrants of this study asserted that they could speak clearly in online classes. This observation was contrary to the report of Khalil et al. (2020) who analyzed the same aspect with reference to students' views. In their study, the Saudi students mentioned voice distortion as one of the difficulties they encountered in e-learning. This dissimilarity could be attributed to the differences in teachers versus students' perspectives. The online teaching and AI techniques also helped mentors in improving their availability to learners, planning courses at the beginning of the semester, and advising students to consult from online resources. Similar results were documented by Mukhtar et al. (2020b) and Zawacki-Richter et al. (2019) as well. The fourth dimension of the study was related to the role of universities in enabling their faculty to use various features of e-learning and AI techniques in the wake of the current pandemic. Our data demonstrated that e-learning and AI techniques assisted instructors in automatic grading and evaluation, better confidentiality of data, improved communication efficiency, easier access to information, and tailoring educational content when needed. Moreover, the faculty members believed that AI techniques were helpful to students to solve their academic issues. Chan and Zary (2019) agreed to such characteristics of online education. The e-learning software are generally equipped with AI techniques that can handle tasks like automatic grading, assessment of learners' performance, and provision of feedback on their progress (Zawacki-Richter et al., 2019). The collected data can then be employed to amend educational content and course plans (Wakelam, Jefferies, Davey, \& Sun, 2014). The current study revealed insights into the adoption and the use of e-learning and AI techniques by Saudi faculty members in higher education. Hence, this research demonstrated a clear picture of the efficacy of e-learning in the current scenario. The faculty members, in response to many of the queries of this research, consented and admired e-learning and AI techniques. E-learning has been adopted throughout the world as a response to the COVID-19 (Bozkurt \& Sharma, 2020). The artificial intelligence tools provide ease, quick response, and essential data for analyzing the success of e-teaching strategies (Chan \& Zary, 2019). Thus, these tools have a significant role to play in online education. Elhajji (2020) suggested that AI techniques could be markedly helpful in learning-teaching in Saudi Arabia; nevertheless, backing from all the stakeholders (government, teachers, and students) was necessary. Therefore, vital support for e-learning and AI platforms is suggested, and a further improvement in relevant educational systems is recommended. In the wake of the current COVID-19 pandemic, this study carries significant importance regarding educational research.

\section{LIMITATIONS}

This study focused on the faculty members' perspectives regarding online teaching and the use of artificial intelligence in the current scenario of the COVID-19 pandemic. In prospective studies, it would be great to explore the learners' viewpoint that would highlight the efficiency of these technologies for the actual beneficiary. Although the sample responses were collected from many of the universities in the country, increasing the number and type of institutions under coverage can further augment the predictability of the data. Moreover, for generalizing the results to other countries, future studies should focus on collecting responses from faculty members from various countries as this study only focused on Saudi academic institutions. Also, in the context of the world's current scenario, it would be interesting to see how the education sector would change in the post-pandemic era.

\section{CONCLUSION, IMPLICATIONS AND FUTURE PERSPECTIVES}

The current study dealt with the role of artificial intelligence techniques in LMS to improve the behavior and practices of faculty members when switching from traditional education to e-learning in light of the COVID-19 
crisis. This study fills the knowledge gap concerning e-learning and AI techniques' relevancy in unpredictable circumstances, i.e., a pandemic in this case. It was discovered that the faculty members in Saudi Arabia had a significant inclination towards e-learning and AI techniques in LMS, and they strongly approved many of the advantages of online teaching. A high percentage of the study samples' responses supported the role of online teaching and AI techniques in improving faculty members' practices in general during the pandemic. Therefore, it can be anticipated that online education and artificial intelligence techniques would play a substantial role in the education sector in the coming years. The current COVID-19 crisis was sudden, and many educators were not equipped with the knowledge of the technicalities involved. Despite these snags, the results of the current study proposed that new doors for online education and using AI techniques in LMS will open as many of the faculty members are trained now, and universities are also investing more resources in this context. This research envisages that e-learning and using AI techniques in LMS have an influential role to play in education even in the post-COVID-19 era. Additionally, the current investigation divulged that the faculty members in Saudi Arabia were embracing e-learning as a beneficial strategy for teaching activities during the pandemic. This research also highlighted that artificial intelligence helped educators automate certain regular tasks, manage their schedules, and tailor their e-teaching practices. This study has paramount importance regarding continuity of education in the context of the COVID-19 pandemic and the role of e-learning and artificial intelligence in education in general.

Funding: The author extends their appreciation to the Deanship of Scientific Research at Saudi Electronic University for funding this work.

Competing Interests: The author declares that there are no conflicts of interests regarding the publication of this paper.

\section{REFERENCES}

Abu-Ayfah, Z. A. (2020). Telegram app in learning English: EFL students' perceptions. English Language Teaching, 13(1), 51-62. Available at: https://doi.org/10.5539/elt.v13n1p51.

Adedoyin, O. B., \& Soykan, E. (2020). Covid-19 pandemic and online learning: The challenges and opportunities. Interactive Learning Environments, 1-13. Available at: https://doi.org/10.1080/10494820.2020.1813180.

Afzal, M. T., Safdar, A., \& Ambreen, M. (2015). Teachers perceptions and needs towards the use of e-learning in teaching of physics at secondary level. American Journal of Educational Research, 3(8), 1045-1051.

Ahmad, S. Z. (2020). Cloud-based collaborative writing to develop EFL students' writing quantity and quality. International Education Studies, 13(3), 51-64. Available at: https://doi.org/10.5539/ies.v13n3p51.

Almohammadi, K., Hagras, H., Alghazzawi, D., \& Aldabbagh, G. (2017). A survey of artificial intelligence techniques employed for adaptive educational systems within e-learning platforms. Journal of Artificial Intelligence and Soft Computing Research, 7(1), 47-64. Available at: https://doi.org/10.1515/jaiscr-2017-0004.

Alqahtani, A. Y., \& Rajkhan, A. A. (2020). Education sciences E-Learning critical success factors during the COVID-19 Pandemic : A comprehensive analysis of E-learning managerial perspectives. Education Sciences, 1O(9), 216.

Alruwais, N., Wills, G., \& Wald, M. (2018). Advantages and challenges of using e-assessment. International Journal of Information and Education Technology, 8(1), 34-37. Available at: https://doi.org/10.18178/ijiet.2018.8.1.1008.

Alshehri, A., Rutter, M., \& Smith, S. (2019). Assessing the relative importance of an E-learning system's usability design characteristics based on students' preferences. European Journal of Educational Research, 8(3), 839-855. Available at: https://doi.org/10.12973/eu-jer.8.3.839.

Andrade, M. S. (2015). Effective elearning and eteaching - a theoretical model. In E-Learning - Instructional Design, Organizational Strategy and Management (1st ed., pp. 33-59). Rijeka, Croatia: IntechOpen.

Arslan, A. (2015). E-learning experience with artificial intelligence supported software: An international application on English language courses E-learning experience with artificial intelligence supported software: An international application on English language cours. GLOKALde Journal, 1(3), 61-75.

Azjen, I., \& Fishbein, M. (1980). Understanding attitudes and predicting social behavior. Englewood Cliffs: Englewood Cliffs Journal. 
Basilaia, G., Dgebuadze, M., Kantaria, M., \& Chokhonelidze, G. (2020). Replacing the classic learning form at universities as an immediate response to the COVID-19 virus infection in Georgia. International Journal for Research in Applied Science and Engineering Technology, 8(3), 101-108. Available at: https://doi.org/10.22214/ijraset.2020.3021.

Bozkurt, A., \& Sharma, R. C. (2020). Emergency remote teaching in a time of global crisis due to CoronaVirus pandemic. Asian Journal of Distance Education, 15(1), 1-6.

Bunce, L., Baird, A., \& Jones, S. E. (2017). The student-as-consumer approach in higher education and its effects on academic performance. Studies in Higher Education, 42(11), 1958-1978. Available at: https://doi.org/10.1080/03075079.2015.1127908.

Butcher, J., \& Rose-Adams, J. (2015). Part-time learners in open and distance learning: Revisiting the critical importance of choice, flexibility and employability. Open Learning: The Journal of Open, Distance and e-Learning, 30(2), 127-137. Available at: https://doi.org/10.1080/02680513.2015.1055719.

Chan, K. S., \& Zary, N. (2019). Applications and challenges of implementing artificial intelligence in medical education: Integrative review. JMIR Medical Education, 5(1), e13930. Available at: https://doi.org/10.2 196/13930.

Chassignol, M., Khoroshavin, A., Klimova, A., \& Bilyatdinova, A. (2018). Artificial Intelligence trends in education: A narrative overview. Procedia Computer Science, 136, 16-24. Available at: https://doi.org/10.1016/j.procs.2018.08.233.

Chick, R. C., Clifton, G. T., Peace, K. M., Propper, B. W., Hale, D. F., Alseidi, A. A., \& Vreeland, T. J. (2020). Using technology to maintain the education of residents during the COVID-19 pandemic. Journal of Surgical Education, 77(4), 729-732. Available at: https://doi.org/10.1016/j.jsurg.2020.03.018.

Contact North Contact Nord. (2018). Ten facts about artificial intelligence in teaching and learning. Retrieved from: https://www.teachonline.ca/sites/default/files/tools-trends/downloads/ten_facts_about_artificial_intelligence_0.pdf.

Crawford, J., Butler-Henderson, K., Rudolph, J., Malkawi, B., Glowatz, M., Burton, R., \& Lam, S. (2020). COVID-19: 20 countries' higher education intra-period digital pedagogy responses. Journal of Applied Learning \& Teaching, 3(1), 1-20. Available at: https://doi.org/10.37074/jalt.2020.3.1.7.

Crown, S., Fuentes, A., Jones, R., Nambiar, R., \& Crown, D. (2011). Anne G. Neering: Interactive chatbot to engage and motivate engineering students. Computers in Education Journal, 21(2), 24-34.

Dhawan, S. (2020). Online learning: A panacea in times of COVID-19 crisis. Educational Technology Systems Magazine, 49(1), 5-22.

Di Gennaro, F., Pizzol, D., Marotta, C., Antunes, M., Racalbuto, V., Veronese, N., \& Smith, L. (2020). Coronavirus diseases (COVID-19) current status and future perspectives: A narrative review. International Journal of Environmental Research and Public Health, 17(8), 2690. Available at: https://doi.org/10.3390/ijerph 17082690.

Dill, E., Fischer, K., McMurtrie, B., \& Supiano, B. (2020). As coronavirus spreads, the decision to move classes online is the first step. What comes next. Retrieved from the chronicle of higher education website: https://www.chronicle.com/article/as-coronavirus-spreads-the-decision-to-move-classes-online-is-the-first-stepwhat-comes-next/.

Dodigovic, M. (2007). Artificial intelligence and second language learning: An efficient approach to error remediation. Language Awareness, 16(2), 99-113. Available at: https://doi.org/10.2167/la416.0.

Duffy, M. C., \& Azevedo, R. (2015). Motivation matters: Interactions between achievement goals and agent scaffolding for selfregulated learning within an intelligent tutoring system. Computers in Human Behavior, 52, 338-348. Available at: https://doi.org/10.1016/j.chb.2015.05.041.

Durlach, P. J., \& Lesgold, A. M. (2012). Adaptive technologies for training and education. New York: Cambridge University Press.

Elhajji, M. (2020). Towards an artificial intelligence strategy for higher education in Saudi Arabia. Paper presented at the 3rd International Conference on Computer Applications and Information Security (ICCAIS), Saudi Arabia.

Farhan, W., Razmak, J., Demers, S., \& Laflamme, S. (2019). E-learning systems versus instructional communication tools: Developing and testing a new e-learning user interface from the perspectives of teachers and students. Technology in Society, 59, 101192 . Available at: https://doi.org/10.1016/j.techsoc.2019.101192. 
Finlayson, H., Maxwell, B., Caillau, I., \& Tomalin, J. (2006). Impact of e-learning in student intermediate and end-point outcomes in further education. London, UK: DfES.

Frazer, C., Sullivan, D. H., Weatherspoon, D., \& Hussey, L. (2017). Faculty perceptions of online teaching effectiveness and indicators of quality. Nursing Research and Practice, 1-6. Available at: https://doi.org/10.1155/2017/9374189.

Gibson, F. (1983). E-learning: Changes in teaching and learning. Social Work Education, 3(1), 4-8. Available at: https://doi.org/10.1080/02615478311220111.

Hakami, M. (2020). Using nearpod as a tool to promote active learning in higher education in a BYOD learning environment. Journal of Education and Learning, 9(1), 119-126. Available at: https://doi.org/10.5539/jel.v9n1p1 19.

Hayes, D. (2017). Beyond McDonaldization: visions of higher education. New York: Taylor \& Francis.

He, B. (2020). Research on the autonomous learning mode of college English via the internet in the epidemic situation. Paper presented at the The 5th International Conference on Social Sciences and Economic Development (ICSSED 2020), China, 127-130, Atlantis Press.

Hussain, M., Zhu, W., Zhang, W., Abidi, S. M. R., \& Ali, S. (2019). Using machine learning to predict student difficulties from learning session data. Artificial Intelligence Review, 52(1), 381-407. Available at: https://doi.org/10.1007/s10462-0189620-8.

Kaur, N., Sahdev, S. L., Chaturvedi, V., \& Rajawat, D. (2020). Fighting COVID-19 with technology and innovation, evolving and advancing with technological possibilities. International Journal of Advanced Research in Engineering and Technology, 11(7), 395-405. Available at: https://doi.org/10.34218/ijaret.1 1.7.2020.039.

Khalil, R., Mansour, A. E., Fadda, W. A., Almisnid, K., Aldamegh, M., Al-Nafeesah, A., \& Al-Wutayd, O. (2020). The sudden transition to synchronized online learning during the COVID-19 pandemic in Saudi Arabia: A qualitative study exploring medical students' perspectives. BMC Medical Education, 20(1), 1-10. Available at: https://doi.org/10.1186/s12909-020-02208-z.

Layali, K., \& Al-Shlowiy, A. (2020). Students' perceptions of E-Learning for Esl/Efl in Saudi universities at time of coronavirus: A literature review. Indonesian EFL Journal, 6(2), 97. Available at: https://doi.org/10.25134/ieflj.v6i2.3378.

Lee, J., March, L., \& Peters, R. (2015). Faculty training and approach to online education: Is there a connection. Retrieved from American University Center for Teaching, Research \& Learning website: https://edspace.american.edu/online/wpcontent/uploads/sites/504/2016/03/FacultyTrainingAndApproachToOnlineEducation.pdf.

Li, F., Qi, J., Wang, G., \& Wang, X. (2014). Traditional classroom vs e-learning in higher education: Difference between students' behavioral engagement. International Journal of Emerging Technologies in Learning (iJET), 9(2), 48-5 1.

Littlefield, J. (2018). The difference between synchronous and asynchronous distance learning. Retrieved from thoughtCo website: https://www.thoughtco.com/synchronous-distance-learning-asynchronous-distance-learning-1097959.

Mukhtar, K., Javed, K., Arooj, M., \& Sethi, A. (2020b). Advantages, limitations and recommendations for online learning during COVID-19 pandemic era. Pakistan Journal of Medical Sciences, 36(4), 27-31. Available at: https://doi.org/10.12669/pjms.36.covid19-s4.2785.

Nagro, S., \& Campion, R. (2017). A method for multimedia user interface design for mobile learning. Paper presented at the 2017 Computing Conference. IEEE.

Nguyen, T. T., Nguyen, Q. V. H., Nguyen, D. T., Hsu, E. B., Yang, S., \& Eklund, P. (2020). Artificial intelligence in the battle against coronavirus (COVID-19): A survey and future research directions. Cornell University website: https://arxiv.org/abs/2008.07343. Preprint arXiv:2008.07343.

Ní Shé, C., Farrell, O., Brunton, J., Costello, E., Donlon, E., Trevaskis, S., \& Eccles, S. (2019). Teaching online is different: Critical perspectives from the literature. Retrieved from Dublin City University website: http://doras.dcu.ie/23890/.

Paudel, P. (2020). Online education: Benefits, challenges and strategies during and after COVID-19 in higher education. International Journal on Studies in Education, 3(2), 70-85. 
Pedro, F., Subosa, M., Rivas, A., \& Valverde, P. (2019). Artificial intelligence in education: Challenges and opportunities for sustainable development. Retrieved from Ministry of Education website: http://repositorio.minedu.gob.pe/handle/20.500.12799/6533.

Raaheim, A., Mathiassen, K., Moen, V., Lona, I., Gynnild, V., Bunæs, B. R., \& Hasle, E. T. (2019). Digital assessment-how does it challenge local practices and national law? A Norwegian case study. European Journal of Higher Education, 9(2), 219231.

Shahzad, A., Hassan, R., Aremu, A. Y., Hussain, A., \& Lodhi, R. N. (2021). Effects of COVID-19 in E-learning on higher education institution students: The group comparison between male and female. Quality \& Quantity, 55(3), 805-826. Available at: https://doi.org/10.1007/s $11135-020-01028-z$.

Shreaves, D. (2019). Faculty perceptions of online teaching at a mid-sized liberal Arts University in the pacific Northwest: A mixed methods study (Doctoral Dissertation). Retrieved from Boise State University website: https://scholarworks.boisestate.edu/td/1580/.

Singh, V., \& Thurman, A. (2019). How many ways can we define online learning? A systematic literature review of definitions of online learning (1988-2018). American Journal of Distance Education, 33(4), 289-306.

Steinberg, M. P., \& Garrett, R. (2016). Classroom composition and measured teacher performance: What do teacher observation scores really measure? Educational Evaluation and Policy Analysis, 38(2), 293-317.

Sun, A., \& Chen, X. (2016). Online education and its effective practice: A research review. Journal of Information Technology Education: Research, 15, 157-190. Available at: https://doi.org/10.28945/3502.

Tayyib, N. A., Ramaiah, P., Alshmemri, M. S., Alsolami, F. J., Lind-say, G. M., Alsulami, S. A., \& Asfour, H. I. (2020). Faculty members' readiness implementing e-learning in higher education Saudi Universities: A cross-sectional study. Indian Journal of Science and Technology, 13(25), 2558-2564.

Timmis, S., Broadfoot, P., Sutherland, R., \& Oldfield, A. (2016). Rethinking assessment in a digital age: Opportunities, challenges and risks. British Educational Research Journal 42(3), 454-476

Toquero, C. M. (2020). Challenges and opportunities for higher education amid the COVID-19 pandemic: The Philippine context. Pedagogical Research, 5(4), emo063. Available at: https://doi.org/10.29333/pr/7947.

Ustünlüoğlu, E. (2016). Perceptions versus realities: Teaching quality in higher education. Education and Science, 41(184), 235250.

Wakelam, E., Jefferies, A., Davey, N., \& Sun, Y. (2014). The potential for using artificial intelligence techniques to improve e-learning systems. Paper presented at the ECEL 2015 Conference Proceedings, (Johnson).

Windiarti, S., Fadilah, N., Dhermawati, E., \& Pratolo, B. W. (2019). Teachers' perception toward the obstacles of e-learning classes. Ethical Lingua: Journal of Language Teaching and Literature, 6(2), 117-128.

Woolf, B. P. (2015). AI and education: Celebrating 30 years of marriage. Paper presented at the In AIED Workshops.

Xu, L. (2019). Narrative based design pedagogy in china's architectural education: Its transplantation, characteristics and impact. Doctoral Dissertation, The Chinese University of Hong Kong (Hong Kong).

Yanti, H., \& Setiawan, A. (2018). Teacher's perception about the use of E-learning/Edmodo in educational activities. Paper presented at the IOP Conference Series: Materials Science and Engineering. IOP Publishing.

Zawacki-Richter, O., Marín, V. I., Bond, M., \& Gouverneur, F. (2019). Systematic review of research on artificial intelligence applications in higher education-where are the educators? International Journal of Educational Technology in Higher Education, 16(1), 1-27. Available at: https://doi.org/10.1186/s41239-019-0171-0.

Views and opinions expressed in this article are the views and opinions of the author(s), International Journal of Education and Practice shall not be responsible or answerable for any loss, damage or liability etc. caused in relation to/arising out of the use of the content. 